\title{
Molecular Microdomains in a Sensory Terminal, the Vestibular Calyx Ending
}

\author{
Anna Lysakowski, ${ }^{1}$ Sophie Gaboyard-Niay, ${ }^{2 \star}$ Irina Calin-Jageman, ${ }^{3 \star}$ Shilpa Chatlani, ${ }^{4}$ Steven D. Price, ${ }^{1}$ \\ and Ruth Anne Eatock ${ }^{5,6}$ \\ ${ }^{1}$ Department of Anatomy and Cell Biology, University of Illinois at Chicago, Chicago, Illinois 60612, 2INSERM U1051, Hôpital Saint Eloi-Bâtiment INM, \\ 34295, Montpellier, France, ${ }^{3}$ Department of Biological Sciences, Dominican University, River Forest, Illinois 60305, ${ }^{4}$ Committee on Neurobiology, \\ University of Chicago, Chicago, Illinois 60637, ${ }^{5}$ Department of Otology and Laryngology, Harvard Medical School, Boston, Massachusetts 02115, and \\ ${ }^{6}$ Eaton-Peabody Laboratories, Massachusetts Eye and Ear Infirmary, Boston, Massachusetts 02114
}

Many primary vestibular afferents form large cup-shaped postsynaptic terminals (calyces) that envelope the basolateral surfaces of type I hair cells. The calyceal terminals both respond to glutamate released from ribbon synapses in the type I cells and initiate spikes that propagate to the afferent's central terminals in the brainstem. The combination of synaptic and spike initiation functions in these unique sensory endings distinguishes them from the axonal nodes of central neurons and peripheral nerves, such as the sciatic nerve, which have provided most of our information about nodal specializations. We show that rat vestibular calyces express an unusual mix of voltage-gated Na and $\mathrm{K}$ channels and scaffolding, cell adhesion, and extracellular matrix proteins, which may hold the ion channels in place. Protein expression patterns form several microdomains within the calyx membrane: a synaptic domain facing the hair cell, the heminode abutting the first myelinated internode, and one or two intermediate domains. Differences in the expression and localization of proteins between afferent types and zones may contribute to known variations in afferent physiology.

\section{Introduction}

In vestibular sensory epithelia of mammals and other amniotes, primary afferents form expanded calyx terminals around type I hair cells in addition to conventional bouton terminals on type II hair cells (Wersäll, 1956). Unlike well known calyces of the auditory brainstem and ciliary ganglion, the vestibular calyx is postsynaptic: its inner face is postsynaptic to the type I hair cell. Its outer face is continuous with the initial segment leading to a heminode where spikes are initiated and is postsynaptic to cholinergic terminals of efferent neurons in the brainstem. This combination of functions provides an opportunity to investigate how nodal proteins interact with synaptic proteins in a compact ending, in contrast to such nodal models as motor neurons and sciatic nerve (Schafer and Rasband, 2006; Lorincz and Nusser, 2008). We find that the calyx expresses novel combinations of

Received Jan. 30, 2011; revised March 21, 2011; accepted May 18, 2011.

Author contributions: A.L., S.G.-N., and I.C.-J. designed research; A.L., S.G.-N., I.C.-J., S.C., and S.D.P. performed research; A.L., S.G.-N., I.C.-J., S.C., and S.D.P. analyzed data; A.L. and R.A.E. wrote the paper.

This study was supported by NIH Grants R01 DC-02521, R01 DC-02058, and R01 DC-02290. The Electron Microscopic Facility of the Research Resources Center of the University of Illinois at Chicago provided equipment and assistance to conduct this study. We are grateful to Drs. Matt Rasband ( $\mathrm{Na}_{\mathrm{v}} 1.6, \mathrm{Na}_{\mathrm{v}} 1.2$, Caspr1, $\beta$ IV spectrin, neurofascin 186, and pan-neurofascin), James Trimmer (pan-Nav ), Elior Peles (Caspr3 and Caspr4), Edward Cooper (KCNQ2 and KCNQ3), Thomas Jentsch (KCNQ4 and KCNQ5), Rock Levinson (pan-Na $a_{\mathrm{V}}$ ), Vann Bennett (ankyrinG and ankyrinB), and Michel Roux (H4, pan-dystrophin) for generous gifts of antibodies, and to Marcin Klapczynski for technical assistance. We thank Drs. Jay M. Goldberg, D. Kent Morest, and Matt Rasband for helpful discussions.

*S.G.-N. and I.C.-J. contributed equally to this work.

The authors declare no competing financial interests.

Correspondence should be addressed to Dr. Anna Lysakowski, Department of Anatomy and Cell Biology, University of Illinois at Chicago, 808 South Wood Street, Chicago, IL 60605. E-mail: alysakow@uic.edu.

DOI:10.1523/JNEUROSCI.0521-11.2011

Copyright $\odot 2011$ the authors $\quad 0270-6474 / 11 / 3110101-14 \$ 15.00 / 0$ ion-channel and tethering proteins, including some that are characteristic of axonal nodes or initial segments (Salzer, 2003; Lai and Jan, 2006).

Type I hair cells release glutamate onto calyces from vesicles arrayed around synaptic ribbons (Bonsacquet et al., 2006; Holt et al., 2007; Dulon et al., 2009). A single calyx ending may receive input from tens of ribbons; in contrast, each bouton ending on a type II cell is generally driven by vesicular release from a single ribbon (Lysakowski and Goldberg, 1997, 2008; Holt et al., 2007). Type I calyx transmission also includes a nonquantal component of unknown mechanism (Yamashita and Ohmori, 1990; Holt et al., 2007), and retrograde vesicular transmission has been suggested (Scarfone et al., 1988; Devau et al., 1993; Scarfone et al., 1996; Chen and Eatock, 2000; Lysakowski and Singer, 2000). Cholinergic efferent terminals on calyx outer faces may provide positive feedback on afferent activity (Holt et al., 2011).

In mammals, afferents from central and peripheral zones of vestibular epithelia form two physiologically distinct populations. Central-zone, "irregular" afferents have variable spike timing and comparatively phasic response dynamics; peripheralzone "regular" afferents have highly stereotyped spike timing and more tonic dynamics (reviewed in Goldberg, 2000; Eatock and Songer, 2011). The two populations do not relate in a simple way to the two types of hair cells and afferent terminals: type I and II hair cells are distributed throughout both zones and supply calyces and boutons of both populations. More subtle zonal differences must be at work. Here we describe zonal variations in calyceal ion channels that may contribute.

Ion channels of interest include three potassium channel families [KCNQ $\left(\mathrm{K}_{\mathrm{V}} 7\right)$, erg $\left(\mathrm{K}_{\mathrm{V}} 11\right)$, and $\mathrm{K}_{\mathrm{V}} 1$ ] that include low- 
voltage-activated channels, which may help set spike timing (Iwasaki et al., 2008; Kalluri et al., 2010). KCNQ and erg channels are present in calyces (Kharkovets et al., 2000; Hurley et al., 2006; Rennie and Streeter, 2006), together with an unusual Na channel, $\mathrm{Na}_{\mathrm{V}} 1.5$ (Wooltorton et al., 2007). We report localization of these channels to specific calyceal subdomains. To investigate how subdomains are established, we also localized contactin-related cell adhesion molecules, scaffolding proteins, and an extracellular matrix protein.

\section{Materials and Methods}

Procedures involving animals were approved by the Institutional Animal Care and Use Committees at the University of Illinois at Chicago.

Choice of antigens. We chose ion channels from those known to be expressed at nodes and initial segments $\left(\mathrm{K}_{\mathrm{V}} 1, \mathrm{KCNQ}, \mathrm{Na}_{\mathrm{V}} 1\right)$ and/or implicated by previous studies on vestibular calyces or eighth-nerve neurons $\left(\mathrm{K}_{\mathrm{V}} 1, \mathrm{KCNQ}\right.$, erg, $\mathrm{Na}_{\mathrm{V}} 1.5$, and $\left.\mathrm{Na}_{\mathrm{V}} 1.6\right) . \mathrm{K}_{\mathrm{V}} 1.1$ and 1.2 subunits form channels that carry subthreshold currents near nodes (Arroyo and Scherer, 2000), and $K_{V} 1$ channels are expressed by vestibular ganglion neurons (Iwasaki et al., 2008; Kalluri et al., 2010). KCNQ $\left(\mathrm{K}_{\mathrm{V}} 7\right)$ channel subunits contribute to $\mathrm{M}$ currents, are expressed at nodes of Ranvier and initial segments of central neurons (Arroyo and Scherer, 2000), and are present in vestibular calyces and neuronal cell bodies (Kharkovets et al., 2000; Hurley et al., 2006; Rennie and Streeter, 2006). Evidence for ethera-go-go-related (erg, $\mathrm{KCNH}, \mathrm{K}_{\mathrm{V}} 11$ ) channel subunits has been obtained from immature calyceal terminals (Hurley et al., 2006). Because nodes express $\mathrm{Na}_{\mathrm{V}}$ channels at high density, we used a pan- $\mathrm{Na}_{\mathrm{V}}$ antibody. We also chose antibodies to two specific $\mathrm{Na}_{\mathrm{V}}$ channels: $\mathrm{Na}_{\mathrm{V}} 1.5$, known to be present in immature vestibular calyces (Wooltorton et al., 2007), and $\mathrm{Na}_{\mathrm{V}} 1.6$, a nodal ion channel that Hossain et al. (2005) localized to the initial segments of auditory afferents.

For scaffolding proteins, we chose those known to tether $\mathrm{Na}_{\mathrm{V}}$ and $\mathrm{K}_{\mathrm{V}}$ channels at or near nodes of Ranvier (Hedstrom et al., 2007; Ogawa and Rasband, 2008): ankyrins B and G, $\beta$ IV spectrin, dystrophin, ezrin, and neurofascin 186. We investigated the cell adhesion molecules (CAMs), contactin and Caspr1 and 2, because they are paranodal or juxtaparanodal in other neurons (Lai and Jan, 2006). We also used an antibody to tenascin-C, an extracellular matrix molecule (ECM) associated with synaptic clefts (Dityatev and Schachner, 2003, 2006) and type I hair cells (Swartz and Santi, 1999; Warchol and Speck, 2007).

Antibodies. For details on primary antibody provenances, see Table 1. Antibodies were obtained from several vendors, including Millipore Bioscience Research Reagents, Alomone, Sigma, United States Biological, Covance, and University of California, Davis/NIH NeuroMab facility. We also obtained antibodies as gifts from Matthew Rasband and Edward Cooper of Baylor College of Medicine, Elior Peles of the Weizmann Institute of Science, Thomas Jentsch of the Max-Delbrück-Centrum for Molecular Medicine, S. Rock Levinson of University of Colorado at Denver, Vann Bennett of Duke University, Álvaro Villarroel of Instituto Cajal and Universidad del País Vasco, and Michel Roux of Université de Strasbourg. The rabbit polyclonal antiserum against pan- $\mathrm{Na}_{\mathrm{V}}$ was made to an epitope common to all subunit subtypes of the voltage-gated $\mathrm{Na}^{+}$channel. Alexa dye-labeled secondary antibodies, made in donkey against rabbit (catalog \#A21206 and A21207), goat (A11055 and A21447) and mouse (A21202 and A21203), were obtained from Invitrogen. Goat antimouse IgG isotype-specific Alexa dye-labeled secondary antibodies were also obtained from Invitrogen (IgG2a, A21131; IgG1, A21125; IgG2b, A21242).

Immunohistochemistry and microscopy. Adult Long-Evans rats of both sexes were deeply anesthetized with Nembutal $(80 \mathrm{mg} / \mathrm{kg})$, then perfused transcardially with $100 \mathrm{ml}$ of physiological saline containing heparin (1000 IU), followed by $2 \mathrm{ml} / \mathrm{g}$ body weight of fixative [ $4 \%$ paraformaldehyde, $1 \%$ acrolein, $1 \%$ picric acid, and $5 \%$ sucrose in $0.1 \mathrm{~m}$ phosphate buffer (PB) at pH 7.4]. Vestibular epithelia were dissected in PB. Some end organs were fixed by immersion and dissection of the temporal bones was done in $100 \% \mathrm{EtOH}$. In some experiments with $\mathrm{Na}_{\mathrm{V}}$ antibodies, rats were perfused with only $4 \%$ paraformaldehyde and $5 \%$ sucrose in 0.1 м PB. Otoconia were dissolved with Cal-Ex (Fisher Scientific) for 10 min. Background fluorescence was reduced by incubating organs and ganglia in a $1 \%$ aqueous solution of sodium borohydride for $10 \mathrm{~min}$, and tissue was cryoprotected in $30 \%$ sucrose-PB overnight at $4^{\circ} \mathrm{C}$. Frozen sections $(35 \mu \mathrm{m})$ were cut with a sliding microtome. Immunocytochemistry was performed on free-floating sections. Tissues were first permeabilized with 4\% Triton X-100 in PBS for $1 \mathrm{~h}$ at room temperature (RT), then incubated with $0.5 \%$ Triton X-100 in a blocking solution of $0.5 \%$ fish gelatin and $1 \%$ BSA in PBS for $1 \mathrm{~h}$ at RT. Ethanol-fixed tissues had no permeabilization pretreatment, although $0.5 \%$ Triton X-100 was sometimes included in the antibody diluent. Sections were incubated with a mixture of two, or in some cases three, primary antibodies for $72 \mathrm{~h}$ at $4^{\circ} \mathrm{C}$. Most primary antibodies were diluted to 1:200 in the blocking solution, except for Caspr 1 (1:250), $\beta$ IV spectrin (1:400), ankyrinB (1:2000), and the Sigma pan- $\mathrm{Na}_{\mathrm{V}}(1: 100)$. We used calretinin antibody as a marker of type II hair cells and calyx afferents. Specific labeling was revealed by incubating sections in a mixture of two secondary antibodies (fluoresceinconjugated donkey anti-goat IgG and rhodamine-conjugated donkey anti-rabbit IgG, diluted 1:200 in blocking solution) for $24 \mathrm{~h}$ at $4^{\circ} \mathrm{C}$. If a third primary antibody was used, then typically Cy5-conjugated donkey anti-mouse was used with fluorescein- or Alexa 488-conjugated donkey anti-goat and rhodamine- or Alexa 594-conjugated donkey anti-rabbit. To be able to combine two different mouse monoclonal antibodies in the same experiment, we used IgG subtype-specific secondary antibodies (Invitrogen). Sections were rinsed with PBS between and after incubations and mounted on slides in Mowiol (Calbiochem).

Controls. In addition to the various controls listed in Table 1, we performed "no primary antibody" controls, which revealed a lack of nonspecific staining. We also confirmed expression of each of the $\mathrm{Na}_{V}$ subunits and erg subunits by performing RT-PCR or by quantitative RT-PCR on whole vestibular ganglia and end organs.

Image analysis. Slides were examined on a laser scanning confocal microscope (LSM 510 META, Carl Zeiss). Final image processing and labeling were done with Adobe Photoshop. Some whole macular organs were processed for various combinations of antibodies; Z stacks of optical sections were then obtained on the confocal microscope, with the thickness of the optical sections varying from 0.4 to $1.0 \mu \mathrm{m}$. The $\mathrm{Z}$-series were deconvolved and reconstructed in 3D with VOLOCITY software (v. 3.7, Improvision).

Immunogold electron microscopy. We investigated ultrastructural localization of some markers with immunogold EM, and we present results here for $\mathrm{Na}_{\mathrm{V}} 1.5$, tenascin-C, and $\beta \mathrm{IV}$ spectrin. Vestibular epithelia were sectioned at $40 \mu \mathrm{m}$ with a Vibratome 2000 (Technical Products International). Free-floating sections were permeabilized with $0.5 \%$ Triton $\mathrm{X}-100$ for $1 \mathrm{~h}$, then blocked in a solution consisting of $0.5 \%$ fish gelatin and $1 \%$ BSA for $1 \mathrm{~h}$. Sections were incubated in primary antibody (1:50 dilution) for $72 \mathrm{~h}$, rinsed, then incubated for $24 \mathrm{~h}$ in secondary antibody (1:40 dilution), tagged with ultra-small $(0.8 \mathrm{~nm})$ colloidal gold-labeled F (ab) goat anti-mouse IgG and goat anti-rabbit IgG (Aurion Cat. No. 25413, distributed in the United States by Electron Microscopy Sciences). Colloidal gold staining was silver-enhanced (4-8 min; IntenSE M kit; GE Healthcare). Sections were dehydrated in a graded series of alcohols and propylene oxide, embedded in Araldite (Fluka Durcupan) on glass slides with plastic coverslips, and polymerized at $55^{\circ} \mathrm{C}$ for $48 \mathrm{~h}$. The section of interest was cut free from the slide, glued on top of a blank Araldite block, sectioned with a diamond knife (DiATOME), and stained with uranyl acetate and lead citrate. Sections were examined and photographed with a JEOL $1220 \times$ transmission electron microscope.

\section{Results}

Colocalization of various ion channels and candidate tethering proteins revealed three to four contiguous domains of the calyx. We have labeled these as domains $1-4$, progressing smoothly from the inner face opposite the presynaptic ribbons (domain 1) up and around the apex of the calyx (domain 2, not always present) to the outer face (domain 3 ) and ultimately the heminode adjacent to the first myelin wrapping (domain 4 ). We present results from each domain in sequence. Throughout, we also note zonal variations in immunolocalization because afferent physiol- 
Table 1. Antibody provenances

\begin{tabular}{|c|c|c|c|c|c|c|c|c|}
\hline \multirow[b]{2}{*}{ Antibodies/antisera } & \multirow[b]{2}{*}{ Source } & \multirow[b]{2}{*}{ Catalog no. } & \multicolumn{5}{|l|}{ Controls } & \multirow[b]{2}{*}{ References } \\
\hline & & & Tested in KO? & Immuno & IP & Western & Pre-absorp & \\
\hline \multicolumn{9}{|l|}{ Structural proteins } \\
\hline Contactin (ms) & NeuroMab & $75-038$ & & $X(O N)$ & & $X$ & & Datasheet \\
\hline Caspr1 (ms) & Rasband/NeuroMab & Gift, 75-001 & $X(w)$ & $X(B r)$ & & $X$ & & Rasband and Trimmer (2001); datasheet \\
\hline Caspr2 (ms) & NeuroMab & $75-075$ & $X(w)$ & $X(B r)$ & & $X$ & & Datasheet \\
\hline Caspr2 (rb) & US Biologicals & C2089-70 & & & & $X$ & & Datasheet \\
\hline Caspr3 (rb) & Peles & Gift & & $X(B r)$ & & $X$ & & Spiegel et al. (2002) \\
\hline Caspr4 (rb) & Peles & Gift & & $X(B r)$ & & $X$ & & Spiegel et al. (2002) \\
\hline AnkyrinB (rb)/(ms) & Bennett/NeuroMab & Gift, 75-144; 75-145 & $X(w$, if $)$ & $X(B r)$ & & $X$ & & Datasheet; Scotland et al. (1998) \\
\hline Ankyring (rb)/(ms) & Bennett/NeuroMab & Gift, 75-146; 75-147 & & $X(B r, 0 N)$ & & & & Datasheet; Kordeli et al. (1995) \\
\hline$\beta I V$ Spectrin (rb) & Rasband & Gift & $X$ (if) & $X(B r, P N S)$ & & $X$ & $X$ & Lacas-Gervais et al. (2004) \\
\hline Pan-neurofascin & Rasband & Gift & & $X(O N)$ & & $X$ & $X$ & Schafer et al. (2004) \\
\hline Neurofascin 186 (ms) & Gow/Rasband & Gift & & $X(S N)$ & & $X$ & & Schafer et al. (2006) \\
\hline Ezrin (ms) & Zymed/Invitrogen & $35-7300$ & & X (cells) & & & & Datasheet \\
\hline Pan-dystrophin (H4) (rb) & Roux/Mornet & Gift & & $X(\mathrm{Rt})$ & & $X$ & & Rivier et al. (1999) \\
\hline Tenascin-C (rb) & Chemicon/Millipore & AB19013 & & $X(H, V)$ & & & $X$ & Datasheet; Huss et al. (2010) \\
\hline Tenascin (gt) & Santa Cruz & SC 9871 & & & & & & Datasheet \\
\hline Neurofilament 165 (ms) & DSHB & $2 \mathrm{H} 3$ & & $X(S C)$ & & & & Dodd et al. (1988) \\
\hline \multicolumn{9}{|l|}{$\mathrm{Na}_{\mathrm{V}}$ channels } \\
\hline $\mathrm{Na}_{\mathrm{V}} 1.1(\mathrm{~ms})$ & NeuroMab & $75-023$ & & $X(B r)$ & & $X$ & & Datasheet \\
\hline $\mathrm{Na}_{\mathrm{V}} 1.2(\mathrm{~ms})$ & NeuroMab & $75-024$ & & $X(B r)$ & & $X$ & & Datasheet \\
\hline Nav1.3 (rb) & Alomone & ASC-004 & & $X(D R G)$ & & $x$ & $X(w)$ & Datasheet \\
\hline $\mathrm{Na}_{\mathrm{V}} 1.5(\mathrm{rb})$ & Chemicon/Millipore & AB5493 & & $X(V, H)$ & & $X$ & $X(w)$ & Datasheet; Wooltorton et al. (2007) \\
\hline $\mathrm{Na}_{\mathrm{V}} 1.6(\mathrm{rb})$ & Alomone & ASC-009 & & $X(S N, B r, D R G)$ & & $X$ & $X(w$, if $)$ & Black et al. (2002) \\
\hline $\mathrm{Na}_{\mathrm{V}} 1.6(\mathrm{rb}) /(\mathrm{ms})$ & Rasband/NeuroMab & Gift, 75-026 & $X$ (if) & $\mathrm{X}(\mathrm{ON}, \mathrm{Br})$ & & & & Rasband et al. (2003); datasheet \\
\hline $\operatorname{Pan} \mathrm{Na}_{\mathrm{V}}(\mathrm{rb})$ & Sigma & S6936 & & & & $X$ & & Datasheet \\
\hline $\operatorname{Pan~Na}_{\mathrm{V}}$ (ms) & Sigma & S8809 & & $\mathrm{X}(\mathrm{ON}, \mathrm{SN}, \mathrm{Br})$ & & $X$ & & Datasheet; Rasband et al. (1999) \\
\hline $\operatorname{Pan~Na}_{v}(\mathrm{rb})$ & Alomone & ASC-003 & & $X(B r)$ & & $X$ & $X(w)$ & Datasheet \\
\hline $\operatorname{Pan~Na}_{V}(\mathrm{~ms})$ & Levinson & Gift & & & & & & Rasband et al. (1999) \\
\hline \multicolumn{9}{|l|}{$\mathrm{K}_{\mathrm{V}}$ channel subunits } \\
\hline $\mathrm{K}_{\mathrm{V}} 1.1(\mathrm{~ms})$ & NeuroMab & $75-007$ & $X(w)$ & $X(\mathrm{Br})$ & & $X$ & & Datasheet \\
\hline $\mathrm{K}_{\mathrm{V}} 1.2(\mathrm{~ms})$ & NeuroMab & $75-008$ & $X(w)$ & $X(B r)$ & & $X$ & & Datasheet \\
\hline KCNQ2-N1 (rb)* urea & Cooper & Gift & & $X(B r)$ & $x$ & $X$ & $X(w$, if $)$ & Cooper et al. (2001); Devaux et al. (2004) \\
\hline KCNQ3-N1 (gp) long & Cooper & Gift & & $X(B r)$ & & $X$ & & Devaux et al. (2004) \\
\hline KCNQ3-C1 (rb) & Cooper & Gift & & $X(B r)$ & $X$ & $X$ & $X(w)$ & Cooper et al. (2000) \\
\hline KCNQ4 (rb) & Jentsch & Gift & $X(w)$ & $X$ & & $X$ & & Kharkovets et al., $(2000,2006)$ \\
\hline KCNQ5 (rb) & Jentsch & Gift & & X (cells) & & $X$ & & Tzingounis et al. (2010) \\
\hline KCNQ5 (rb) & Villarroel & Gift & & & & & & Yus-Nájera et al. (2003) \\
\hline ERG1 (rb) & Chemicon/Millipore & AB5222 & & $X(V)$ & & $X$ & $X(w)$ & Datasheet; Hurley et al. (2006) \\
\hline ERG2 (rb) & Alomone & APC-114 & & $X(B r)$ & & $X$ & $X(w)$ & Datasheet \\
\hline ERG3 (rb) & Alomone & APC-112 & & $X(B r)$ & & $X$ & $X(w)$ & Datasheet \\
\hline MiRP1 (rb) & Chemicon/Millipore & AB5845 & & & & $X$ & $X(w)$ & Datasheet \\
\hline SK2 (rb) & Chemicon/Millipore & AB5356 & & $X(B r)$ & & $x$ & & Datasheet \\
\hline \multicolumn{9}{|l|}{ Myelin basic protein } \\
\hline $\mathrm{MBP}(\mathrm{ms})$ & Covance & SMI-99P & & $X(B r)$ & & $X$ & & Datasheet \\
\hline \multicolumn{9}{|l|}{ Calretinin } \\
\hline Calretinin (gt) & Chemicon/Millipore & AB1550 & & $X(B r, \mathrm{Rt})$ & & $X$ & $X(w)$ & Datasheet; Desai et al. (2005) \\
\hline Calretinin (rb) & Chemicon/Millipore & AB5054 & & $X(\mathrm{Br})$ & & $X$ & $X(w)$ & Datasheet \\
\hline Calretinin (ms) & Chemicon/Millipore & MAB1568 & & $X(B r)$ & & $X$ & & Datasheet \\
\hline
\end{tabular}

KO, Knock-out; Immuno, immunohistochemistry; Western, Western blot; IP, immunoprecipitation; Pre-absorp, preabsorption; ms, mouse; rb, rabbit; gt, goat; gp, guinea pig; Br, brain; 0N, optic nerve; $\mathrm{SN}$, sciatic nerve; $\mathrm{V}$, vestibular tissue; $\mathrm{H}$, heart; Rt, retina; PNS, peripheral nervous system; DRG, dorsal root ganglia; SC, spinal cord; w, Western blot; if, immunofluorescence; ip, immunoperoxidase.

ogy and synaptic and afferent morphology vary with zone. Note that we often used calretinin to mark afferent type and epithelial zone. Among afferents, calretinin selectively labels calyx-only afferents, which have distinctive physiology and whose calyceal terminals delineate the central zones of cristae and the striolar zones of the utricular and saccular maculae (Desai et al., 2005a,b). In rats and mice, calretinin also labels type II hair cells (Desai et al., 2005a,b). Because striolar and extrastriolar zones of maculae resemble the central and peripheral zones, respectively, of cristae, we have simplified the text by referring to zones in both cristae and maculae as "central" and "peripheral." Bouton-only afferents, which innervate only type II cells, are restricted to peripheral zones, and dimorphic afferents, which make both calyceal endings on type I cells and bouton endings on type II cells, are found throughout the epithelia.
KCNQs, $\mathrm{K}_{\mathrm{V}} 1.1$, Caspr1, tenascin- $\mathrm{C}$, and $\mathrm{Na}_{\mathrm{V}} 1.5$ delineate domain 1 on the calyx inner face

In type I hair cells, synaptic ribbons and their associated vesicles are arrayed next to the basolateral cell membrane in the basal part of the cell and extending part way up the sides. The number and extent of the ribbons are larger in central type I cells than in peripheral type I cells (Lysakowski and Goldberg, 1997). Previous work on immature rat epithelia (Hurley et al., 2006) showed KCNQ4 (K $\left.\mathrm{K}_{\mathrm{V}} 7.4\right)$ immunoreactivity on the calyx inner face opposite the synaptic ribbons (RS) of the hair cell (domain 1), illustrated in the schematic of Figure 1. Here we show that KCNQ4 labeling of domain 1 is more intense in adult calyces (P60-P180) and that it overlaps with strong immunoreactivity for other voltage-gated $\mathrm{K}$ and $\mathrm{Na}$ channel subunits.

Figure $1(A-C)$ shows labeling of the calyx inner face with antibodies to KCNQ2 (Fig. $1 A$ ) and KCNQ5 (Fig. $1 B, C$ ) in approxi- 

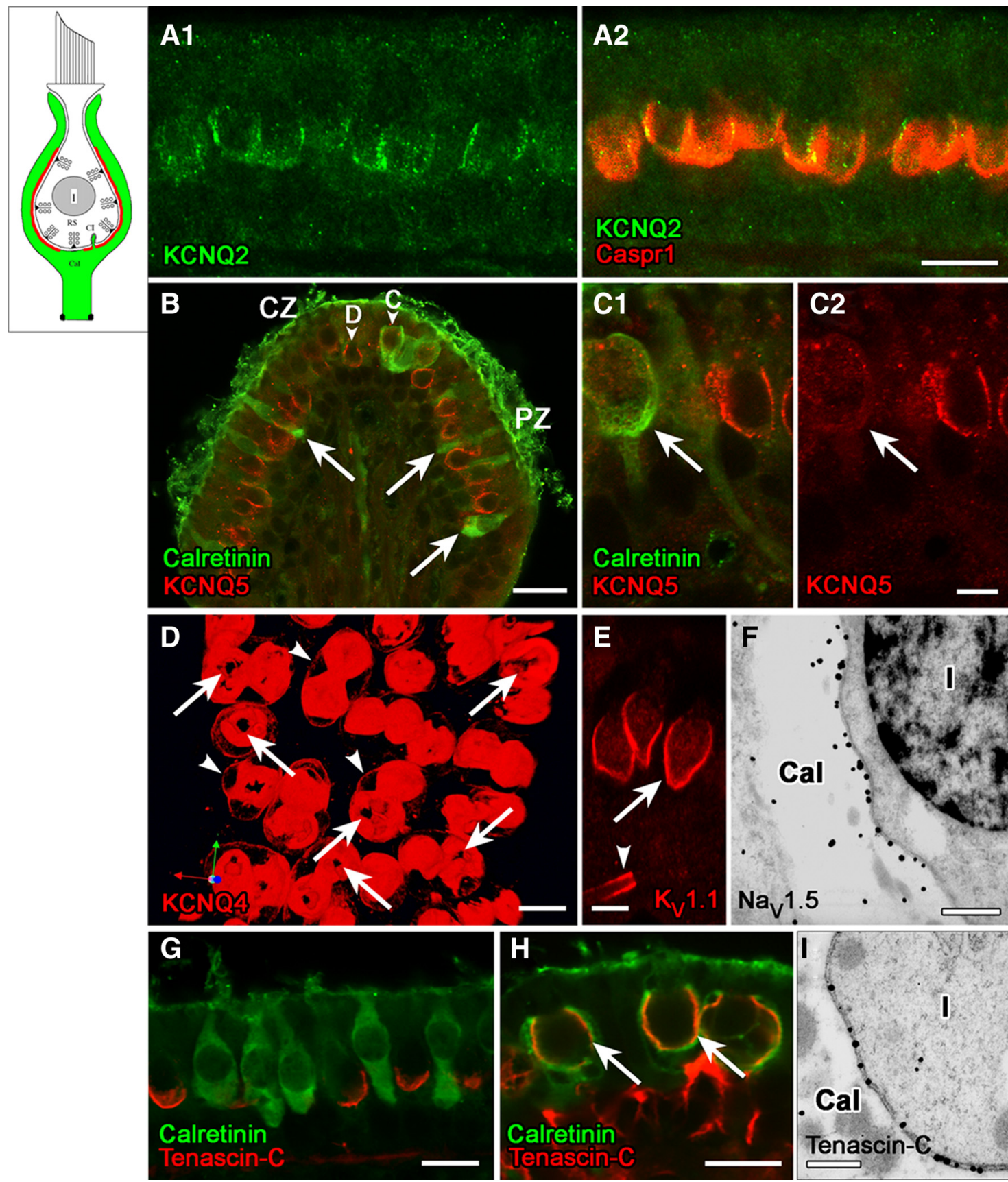

Figure 1. Domain 1 of the calyx ending, facing the zone of presynaptic ribbons (RS) in the type I hair cell, is strongly immunoreactive for voltage-gated Kand Na channels and associated proteins. Schematics in the upper left corner of Figures $1-4$ delineate the successive domains in red. $\boldsymbol{A}$, KCNQ2 immunostaining ( $\boldsymbol{A} \boldsymbol{1}$, green) on the inner surface of the calyx ending, where it colocalized with Caspr1 (A2, red). B, C, KCNQ5 antibody (red) labeled the inner surface of calyces of both central-zone (CZ) and peripheral-zone (PZ) dimorphic (D) afferents (B, C1, C2, calretinin-negative), but not calyx-only (C) afferents ( $B,(1)$. Calretinin antibody ( $B, C 1$, green) selectively labels type Il hair cells (arrows) and calyx-only (C) afferents, not dimorphic (D) afferents. Localization of the KCNQ5 label to the calyx membrane (rather than, e.g., the hair-cell membrane) was determined by immunogold EM (data not shown). $\boldsymbol{D}$, Top view of a whole-mount utricular macula, stained with KCNQ4 antibody (red). The antibody stained the calyx membrane intensely on its inner face (domain 1) and lightly on its outer face

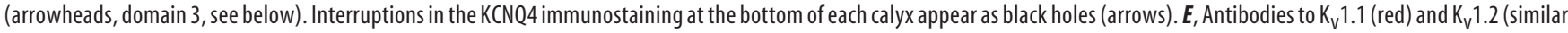
pattern but not shown) also label domain 1 (arrow) in all calyces, in addition to labeling membrane of the nerve fiber near the first internode (the juxtaparaheminodal membrane, arrowhead). $F$, Immunoreactivity for $\mathrm{Na}_{\mathrm{v}} 1.5$ subunit was restricted to the calyx inner membrane, as shown here for a calyx (Cal) surrounding a type I hair cell (I); the calyx belonged to a dimorphic afferent in the peripheral zone of a crista. $G$, Antibody to tenascin- $C$ (red) formed cup-like labeling at the base of type I hair cells, but not calretinin-positive type II hair cells (green) in the extrastriolar (peripheral) zone of the utricular macula. $\boldsymbol{H}$, Tenascin-C forms much larger cups on these striolar calyces than on the extrastriolar calyces of $\boldsymbol{G}$. Staining for tenascin- $C$ (red) and calretinin (green) overlaps in confocal images, producing a yellow color in domain 1 (arrows) of calyx-only afferents in the striolar (central) zone. Tenascin- $C$ antibody also labeled extracellular matrix in the tissue stroma below the sensory epithelium (see red stain below right-hand calyces). $I$, The higher resolution of immunogold EM revealed that tenascin- $C$ is neither in the hair cell nor in the calyx, but rather in the synaptic cleft between the two (thus, the overlap in tenascin- $C$ and calretinin in $\boldsymbol{H}$ reflects proximity of the antigens rather than colocalization, an underappreciated likelihood in most confocal studies). Shown are tenascin-C-immunolabeled gold particles in the synaptic cleft of a calyx in a crista peripheral zone. Such particles were not seen in the synaptic clefts of bouton synapses on type ll hair cells (not shown). Scale bars: $\boldsymbol{A}, \boldsymbol{D}, \boldsymbol{G}, \boldsymbol{H}, 10 \mu \mathrm{m} ; \boldsymbol{B}, 20 \mu \mathrm{m} ; \boldsymbol{C}, \boldsymbol{E}, 5 \mu \mathrm{m} ; \boldsymbol{F}, I, 500 \mathrm{~nm}$. 
mately the same location as previously reported for KCNQ4 (Kharkovets et al., 2000; Hurley et al., 2006). KCNQ4 immunoreactivity shows zonal variation that mirrors the extent of presynaptic ribbons: it is both more intense and extends farther apically in central calyces than peripheral calyces (Lysakowski and Price, 2003). In contrast, KCNQ2 appeared not to vary with zone or afferent type, whereas KCNQ5 immunoreactivity did not vary with zone but did vary with afferent type. As shown in Figure 1, $B$ and $C$, KCNQ5 staining was seen in the calyx endings of dimorphic afferents, which are found in both zones and are calretinin-negative. KCNQ5 was not localized to calretinin-positive calyx-only afferents, which are found only in central zones and have distinctive physiology (for review, see Lysakowski and Goldberg, 2004).

To provide a more complete picture of KCNQ4 immunolabeling, we generated three-dimensional reconstructions of confocal stacks of optical sections (Fig. 1D). These pictures reveal "holes" in the intense KCNQ4 label: 1-3 large holes (1-3 $\mu \mathrm{m}$ diameter) at the bottom of each calyceal cup and smaller holes $(200-400 \mathrm{~nm})$ at calyceal invaginations, where the calyx membrane pushes into the hair cell and the synaptic cleft narrows (Spoendlin, 1966). The invaginations are especially numerous in the large synaptic domains of central-zone calyces (Lysakowski and Goldberg, 1997) and may serve to fasten the hair cell and calyx together, like punctae adherens in the calyx of Held. The small holes in KCNQ4 immunolabel are reminiscent of freeze-fracture material showing that invaginations are devoid of membrane particles (Gulley and Bagger-Sjöbäck, 1979).

The low-voltage-activated channel, $\mathrm{K}_{\mathrm{V}} 1.1$, is, like KCNQ2, expressed in domain 1 in all calyces, both central and peripheral (Fig. $1 E) . \mathrm{K}_{\mathrm{V}} 1.1$ is thus a candidate for the dendrotoxin-sensitive conductance of some vestibular ganglion somata, which has a strong impact on firing pattern (Iwasaki et al., 2008; Kalluri et al., 2010).

$\mathrm{Na}_{\mathrm{V}} 1.5$, a tetrodotoxin-insensitive subunit best known as the cardiac $\mathrm{Na}$ channel, is also concentrated in domain 1 (Fig. $1 F$ ). The localization strongly overlaps that of KCNQ4 and, like KCNQ4 immunoreactivity, is seen in all calyces but is more intense in central zones.

What molecules bind these voltage-gated ion channels to domain 1? Sousa et al. (2009) showed that localization of KCNQ4 subunits in the calyx inner face requires the cell adhesion molecule Caspr1. Caspr 1 is strongly expressed in domain 1 (Fig. 1 A2), as is a related CAM, contactin (see domain 4, below). Although both KCNQ2 and $\mathrm{Na}_{\mathrm{V}}$ subunits have a binding motif for the scaffolding protein ankyrinG (Cooper, 2011), we found no ankyrinG in domain 1. This negative finding was strengthened by staining for ankyrinG in the same tissue sections at heminodes (see domain 4, below), where it did colocalize with KCNQ2 and $\mathrm{Na}_{\mathrm{V}}$ subunits. The ECM protein, tenascin-C, has been described as a marker of type I hair cells (Swartz and Santi, 1999; Warchol and Speck, 2007). In confocal material (Fig. $1 G, H$ ), tenascin-C is closely associated with domain 1 . In ultrastructural material, however, we show that tenascin-C is in the synaptic cleft, congruent with a dense cleft substance (Fig. $1 I$ ) that may contain other proteins. Like the presynaptic ribbons and the calyceal immunoreactivity for $\mathrm{Na}_{\mathrm{V}} 1.5$ and KCNQ4, tenascin-C label showed regional variation in extent, reaching farther up from the base of the calyceal cup in central/striolar than peripheral/extrastriolar zones (Fig. 1, compare panels $G$ and $H$ ). Tenascin-C has been linked in neurons to synaptic plasticity involving L-type calcium channels (Dityatev et al., 2010). L-type channels are expressed by vestibular hair cells (Bao et al., 2003; Dou et al., 2004), where they mediate transmitter release, and by primary vestibular neurons (Chambard et al., 1999). Alterna- tively or additionally, tenascin-C might help stabilize the $\mathrm{Na}_{\mathrm{V}}$ channels (Srinivasan et al., 1998).

In summary, domain 1 , which is coextensive with synaptic ribbons in the type I hair cell, includes multiple KCNQ and $\mathrm{K}_{\mathrm{V}} 1$ subunits in addition to $\mathrm{Na}_{\mathrm{V}} 1.5$. KCNQ2, $\mathrm{K}_{\mathrm{V}} 1.1$, and $\mathrm{K}_{\mathrm{V}} 1.2$ are expressed in calyces regardless of type (calyx-only and dimorphic) or zone (central or peripheral). KCNQ4 and $\mathrm{Na}_{\mathrm{V}} 1.5$ are also expressed in all calyces, but staining is most intense and extensive in central calyces. KCNQ5 is restricted to dimorphic afferents of both zones. Caspr1, contactin, and tenascin- $\mathrm{C}$ are all candidates for localizing specific proteins and functions to this domain. Differential expression of these proteins with zone (KCNQ4, $\mathrm{Na}_{\mathrm{V}} 1.5$, and tenascin-C) or afferent type (KCNQ5) may contribute to known physiological differences between afferent fiber populations.

\section{Caspr2 demarcates domain 2, an apical domain of the calyx membrane}

The high density of $\mathrm{K}_{\mathrm{V}}$ channel subunits and Caspr1 prompted us to probe the calyx inner face for additional membrane proteins found near nodes of Ranvier. On the calyces of dimorphic afferents, Caspr2, a CAM typically expressed in axonal juxtaparanodes (Peles and Salzer, 2000; Salzer, 2003), labeled the apical part of the inner face, extended around the apex and approximately one-third to half way down the outer face (Fig. $2 \mathrm{~A}$, right hair cell). We refer to this domain of intense Caspr2 labeling as domain 2. Less intense label was seen on the outer face at the base. High-magnification views of cross-sections through the apical half of the calyx revealed two concentric circles, indicating surface labeling on both the inner and outer membranes (Fig. $2 B$, inset). The labeling is much stronger in the peripheral (extrastriolar) zone (Fig. 2 B), partly because many of the calyces of central, calyx-only afferents lack the apical part, or neck, of domain 2. Figure $2 \mathrm{~A}$ illustrates this difference: domain 2 is labeled by Caspr2 in the right calyx but is truncated in the left calyx. Calretinin labeling shows that the left calyx belongs to a calyx-only (calretinin-positive) afferent, and the right calyx belongs to a dimorphic (calretinin-negative) afferent. In a count of calretininpositive calyces, approximately two-thirds (57/86) were truncated in this way, and most of the remainder had small neck regions. This striking anatomical difference may also play a role in the physiological differences between calyx-only and dimorphic afferents.

Caspr2 staining overlaps with staining for $\operatorname{erg} 1\left(\mathrm{~K}_{\mathrm{V}} 11.1\right)$ subunits (Fig. 2C) and erg2 ( $\mathrm{K}_{\mathrm{V}} 11.2$; data not shown). The same concentric pattern of circles shown for Caspr2 was seen with erg staining in peripheral-zone calyces (data not shown), indicating that erg channels are present on both faces. Thus, Caspr2 is a candidate for tethering erg subunits in place, just as Caspr1 does for KCNQ4 subunits in domain 1 (Sousa et al., 2009). Domain 2 in dimorphic afferents also has an apical band of immunoreactivity for $\beta$ IV spectrin (Fig. $2 D, E$ ), a nodal scaffolding protein (Schafer and Rasband, 2006).

Domain 2 is defined not just by the presence of Caspr2, but also by the absence of other proteins. For example, dystrophin expression in domains 1 and 3 stops abruptly at the border with domain 2 (Fig. $2 F$ ). Dystrophins are cytoskeletal glycoproteins frequently associated with $\mathrm{Na}_{\mathrm{V}}$ channels and certain $\mathrm{K}_{\mathrm{V}}$ subunits, for example, KCNQ3 (Byers et al., 1991, 1993; Saito et al., 2003). The absence of dystrophin from domain 2 may account for the lack of pan- $\mathrm{Na}_{\mathrm{V}}$ labeling in this domain (Fig. $3 A$; see below). KCNQ3 immunoreactivity was strongly present in domains 3 and 4 , as described below, but was absent from domain 2 . 

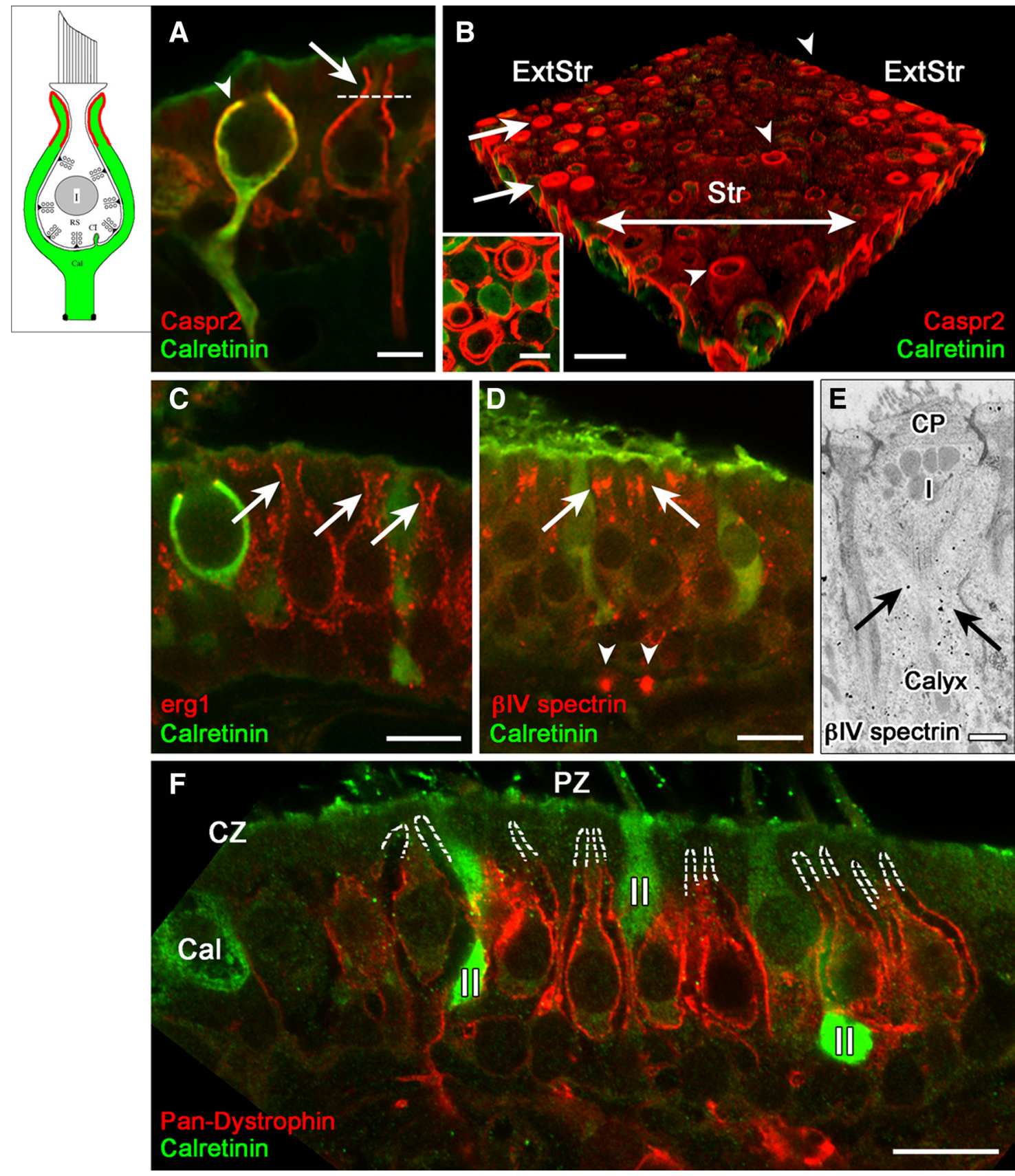

Figure 2. Domain 2, the apical part of the calyx, was selectively labeled by antibodies to the cell adhesion molecule, Caspr2, and to erg $\mathrm{K}_{\mathrm{v}}$ subunits, and lacked several proteins found in domain 3. A, B, Caspr2 antibody (red) outlines domain 2: the apical part of the calyx (above the dashed line in $\boldsymbol{A}$ ). These central calyces belong to a calyx-only (calretinin-positive) and a dimorphic (calretinin-negative) afferent. Domain 2 extends higher in dimorphic afferents ( $\boldsymbol{A}, \boldsymbol{B}$, arrows) than in most calyx-only afferents ( $\boldsymbol{A}$, arrowhead), as shown in confocal transverse sections $(\boldsymbol{A})$ and $3 \mathrm{D}$ reconstructions of whole-mount utricular maculae $(\boldsymbol{B})$. In $\boldsymbol{B}$, the striola (Str) had much less Caspr2 staining (red) than did the extrastriolar region (ExtStr). Arrowheads in $\boldsymbol{B}$ indicate Caspr2 label of three calyces of striolar dimorphic afferents, which extended to the apical surface of the epithelium. A transverse optical section of domain 2 (inset), taken above the level of the dotted line in $\boldsymbol{A}$, shows concentric circles of Caspr2 label, demonstrating that it is present on both the inner and outer calyx surfaces. $C$, Domain 2 was labeled by antibodies to erg1 and erg2 (data not shown), but not by any of the other $K_{V}$ antibodies we used (KCNQ2, 3, 4, 5; $K_{v} 1.1$, 1.2). Erg1 antibody labeled domain 2 in calretinin-negative dimorphic afferents (arrows) but not in calyx-only afferents, as shown by the calretinin-positive (green) calyx on the left. Erg2 (data not shown) had a similar distribution. $\boldsymbol{D}, \boldsymbol{E}$, Immunoreactivity for $\beta$ IV spectrin, which is usually found at nodes (arrowheads in $\boldsymbol{D}$ point to heminodes on the afferent fibers) and axonal initial segments, is also found in domain 2 (arrows), shown by both confocal immunohistochemistry (D) and EM immunogold localization. $\boldsymbol{E}$, Note the gold particles (arrows) in the calyx surrounding the upper part of a type I (I) hair cell below the cuticular plate (CP). $\boldsymbol{F}$, Domain 2 is also defined by the absence of several domain 3 proteins, including dystrophin (red); dashed white lines outline the unlabeled domain 2 in several calyces of peripheral-zone (PZ) dimorphic afferents. Dimorphic afferents are calretinin-negative, unlike central-zone (CZ) calyx-only afferents (green, Cal) and peripheral-zone (PZ) type II hair cells (II). Scale bars: $\boldsymbol{A}, \boldsymbol{B}$ inset, $5 \mu \mathrm{m} ; \boldsymbol{B}-\boldsymbol{D}, \boldsymbol{F}, 10 \mu \mathrm{m} ; \boldsymbol{E}, 500 \mathrm{~nm}$.

$\mathrm{Na}_{\mathrm{V}}$ channels, dystrophin, KCNQ3, and ankyrin B define domain 3 on the calyx outer face

Domain 3 comprises the basal outer face of the calyx and most of the unmyelinated part of the fiber immediately below the calyx
(Fig. 3, inset). This domain was labeled by pan- $\mathrm{Na}_{\mathrm{V}}$ antibody made against an epitope common to all $\mathrm{Na}_{\mathrm{V}} \alpha$ subunits (Fig. $3 A$ ). The complex pattern of labeling, which also included domains 1 and 4 and hair cells, is likely to reflect expression of multiple $\mathrm{Na}_{\mathrm{V}}$ 

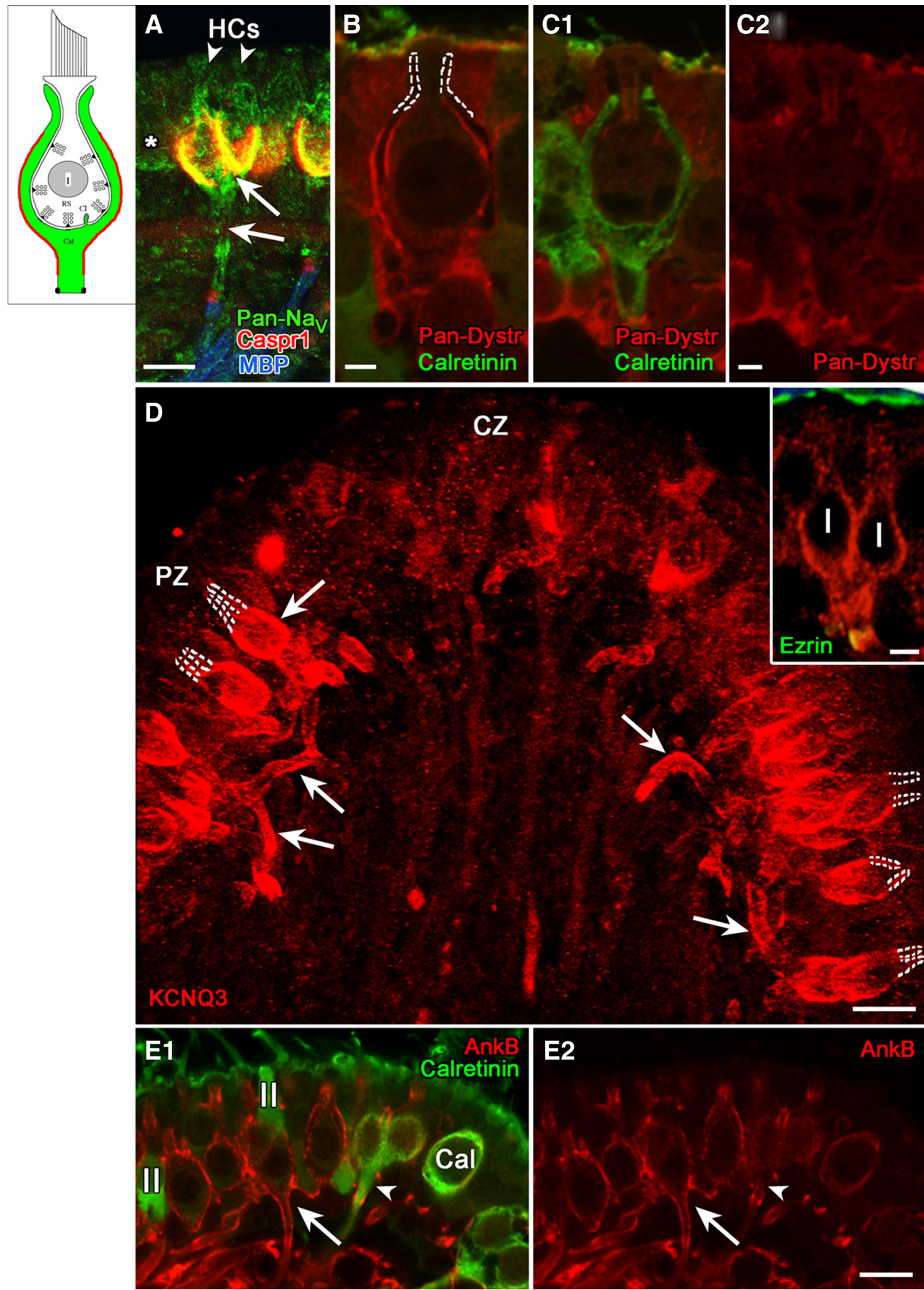

Figure 3. Domain 3, comprising the basolateral calyx and the stretch of axon leading to the heminode, selectively expressed $\mathrm{Na}_{\mathrm{V}}$ channels, KCNQ3, and certain scaffolding proteins. A, Pan-Na antibody produced a complex pattern of label, including domains 1 and 3 (arrows) and the heminode (domain 4), as well as type I hair cells (arrowheads) and adjacent type II hair cells (asterisk). $\boldsymbol{B}$, C, Pan-dystrophin (Pan-Dystr, red) labeled domain 3 of dimorphic (calretinin-negative), but not calyx-only (calretinin-positive, green) afferents (compare $\boldsymbol{B}$ with $\mathbf{C}$ and $\mathbf{C 2}$ ). D, Domain 3 in peripheral-zone dimorphic afferents was intensely immunoreactive for KCNQ3, as shown by this flattened projection of a stack of confocal images. KCNQ3 staining (arrows) extended throughout domain 3 from the basolateral outer surface of the calyx to the heminode. Note the lack of stain in domain 2, marked by dashed white lines. The inset shows a higher magnification single image of a dimorphic afferent with a "complex" calyx ending that envelops two adjacent type I hair cells. Antibody to ezrin (green) labeled the apical microvilli of the sensory epithelium and the heminode, where it combined with the red KCNQ3 immunolabel to form a yellow band. $\boldsymbol{E}$, AnkyrinB antibody labeled domain 3 in dimorphic afferents (E1, E2, red, long arrows) but not calyx-only afferents (E1, $E 2$, green, arrowheads). Scale bars: $A, D, E, 10 \mu \mathrm{m} ; \boldsymbol{D}$, inset, $5 \mu \mathrm{m} ; \boldsymbol{B}, \boldsymbol{C}, 2 \mu \mathrm{m}$. 
isoforms. For example, pan- $\mathrm{Na}_{\mathrm{V}}$ labeling of domain 1 may correspond to $\mathrm{Na}_{\mathrm{V}} 1.5$ given its similarity to the $\mathrm{Na}_{\mathrm{V}} 1.5$-like immunoreactivity in Figure $1 F$. The pan- $\mathrm{Na}_{\mathrm{V}}$ staining in hair cells may correspond to $\mathrm{Na}_{\mathrm{V}} 1.5$ and/or $\mathrm{Na}_{\mathrm{V}} 1.2$, based on reports from younger rats (Chabbert et al., 2003; Wooltorton et al., 2007) and our unpublished observations with subunit-specific antibodies in adult rats (S. Gaboyard and A. Lysakowski). We saw significant differences between afferent types (dimorphic vs calyx-only) in labeling of domain 3 for certain ion-channel-associated proteins, which again suggests differences in their ion channel expression. Pan-dystrophin antibody labeled both faces (domains 1 and 3 ) of the calyces of dimorphic afferents (Fig. 3B) but not the calyces of calyx-only afferents (Fig. $3 C$ ). Thus, $\mathrm{Na}_{\mathrm{V}}$ subunit expression may differ between calyxonly and dimorphic calyces. Furthermore, given the strong staining for $\mathrm{Na}_{\mathrm{V}} 1.5$ in domain 1 of calyx-only afferents (Fig. $1 \mathrm{~F}$ and Wooltorton et al., 2007), it appears that $\mathrm{Na}_{\mathrm{V}} 1.5$ is not coupled to dystrophin.

Expression in domain 3 also differed between zones. Staining with an antibody to KCNQ3, a marker of nodes of Ranvier and axonal initial segments (Chung et al., 2006; Schwarz et al., 2006), was much more intense in domain 3 of peripheral calyces than in central calyces (Fig. 3D). Domain 2 was not labeled (see dashed outlines of domain 2 in Fig. 3E). Weak KCNQ4 immunoreactivity was also present in domain 3 , but was much less intense than in domain 1 (Fig. 1D).

An antibody to ankyrinB, a paranodal scaffolding protein associated with $\mathrm{K}_{\mathrm{V}}$ channels (Scotland et al., 1998; Ogawa et al., 2006), labeled the unmyelinated terminal segments of dimorphic afferents but not calyx-only afferents (Fig. 3D). In dimorphic calyces, ankyrinB immunofluorescence formed a thin shell along the outer face, continuing below the calyx (Fig. $3 E$, long arrows) and becoming more intense near the heminode. For calyx-only afferents, ankyrinB labeling was only seen at the heminode (Fig. 3E, short arrows).

In summary, domain 3 in dimorphic afferents is defined by expression of $\mathrm{Na}_{\mathrm{V}}$ and specific $\mathrm{K}_{\mathrm{V}}$ channels and associated proteins. The staining for pan-dystrophin, ankyrinB, and KCNQ3 differs between zones, in part because domain 3 of the calyx-only afferents is not stained and these constitute a significant fraction of central afferents $(\approx 50 \%$ in crista, $25 \%$ in macula of chinchilla; Fernández et al., 1988, 1990). These zonal variations in domain 3 ion channel expression may influence firing pattern differences between afferent populations.

\section{Nodal and ion channel proteins label domain 4 , the heminodal membrane next to the myelin}

Domain 4 is the heminode, a stretch of approximately $1 \mu \mathrm{m}$ on the afferent fiber adjacent to the first internode. The first internode can be visualized by staining its myelin sheath with antibody against myelin basic protein (Fig. 4A, blue label). The heminode and nodes farther along the afferent were selectively labeled by antibodies against the nodal proteins $\mathrm{Na}_{\mathrm{V}} 1.6$ (Fig. $4 A$ ), $\beta \mathrm{IV}$ spectrin (Fig. $4 B$ ), neurofascin 186 (Fig. 4C), pan-dystrophin (Fig. 4D), ezrin (Fig. 3D, inset), and ankyrinG (data not shown). Labeling for these nodal markers generally did not extend distally along the unmyelinated fiber toward the calyx, justifying the delineation of this portion of the axon as a separate domain. Restriction of $\mathrm{Na}_{\mathrm{V}} 1.6$ staining to the heminode and nodes (Fig. $4 A$, inset) in dimorphic, but not calyx, afferents indicates that other $\mathrm{Na}_{\mathrm{V}}$ subunits are responsible for the pan- $\mathrm{Na}_{\mathrm{V}}$ staining of domains 3 and 4 (Fig. $3 A$ ).

KCNQ staining of domain 4 differed strongly between calyxonly and dimorphic afferents. Heminodes of calyx-only afferents stained intensely for KCNQ4 (Fig. $4 E, F$ ). Three-dimensional reconstructions of nerve fibers showed that KCNQ4 immunoreac- tivity formed a ring around the cytosolic calretinin label of calyxonly fibers (Fig. $4 E, F$, long arrows), consistent with membrane localization of the channels. In contrast, heminodes below the calyces of dimorphic afferents expressed KCNQ3, as shown by colocalization of KCNQ3 and ezrin staining (Fig. 3D, yellow in inset).

Caspr1 (Fig. 4A), contactin (Fig. 4G), and ankyrinB (Fig. 3D) antibodies labeled the paraheminodal membrane distal to the heminode. The paraheminodal contactin staining (Fig. 4G, arrowheads) shows that the peripheral-zone heminodes are well below the basement membrane of the epithelium, much farther from the hair cells than are central-zone heminodes (Fig. $4 F$, long arrows).

Antibodies to $\mathrm{K}_{\mathrm{V}} 1.1$ (Fig. $1 E$ ), $\mathrm{K}_{\mathrm{V}} 1.2$ (data not shown), and Caspr2 (data not shown) labeled the juxtaparaheminodal membrane beyond domain 4 (beneath the myelin), as seen at juxtaparanodes in other neurons.

\section{Discussion}

\section{Functional significance of different microdomains}

The vestibular calyx integrates afferent signals from hair cells and efferent signals from the brain into spike activity representing head motions. Calyces in different zones contribute to afferents with distinct discharge patterns and response properties. The localization of ion channels and various associated proteins suggests that these large synaptic cups, previously thought of as uniform, are divided into several discrete domains (Fig. 5), from a postsynaptic domain 1 deep in the calyceal cup to the heminodal domain 4 adjacent to the first myelin wrapping (Table 2, Fig. 5). In addition to ion channels, the domains express a number of scaffolding, CAM, and ECM proteins characteristic of axonal nodes and initial segments. Our results support the hypothesis that differences in molecular organization of these domains, between zones and between calyx-only and dimorphic afferents, may help differentiate the discharge patterns of irregular afferents and regular afferents (Smith and Goldberg, 1986; Baird et al., 1988; Goldberg et al., 1990b; Kalluri et al., 2010).

Domain 1 comprises much of the calyceal inner face and is contiguous with a dense substance in the intervening synaptic cleft, apposing the synaptic ribbons. Indeed, the extent of the immunolabeled cups (Fig. 5A-F) covaries with hair cell membrane devoted to transmitter release, as reflected by adjacent synaptic ribbons. Ribbons cluster in the bottom third in peripheralzone type I hair cells but in the bottom two-thirds of central-zone type I hair cells (Lysakowski and Goldberg, 1997). Therefore, in addition to the proteins shown here, domain 1 also expresses glutamate receptors-principally AMPA-type, but also NMDA receptors (Matsubara et al., 1999; Bonsacquet et al., 2006).

Domain 1 has an impressively dense expression of $\mathrm{K}_{\mathrm{V}}$ and $\mathrm{Na}_{\mathrm{V}}$ channels. $\mathrm{K}_{\mathrm{V}}$ channels include multiple KCNQ $\left(\mathrm{K}_{\mathrm{V}} 7\right)$ and erg $\left(K_{V} 11\right)$ channel isoforms as well as $K_{V} 1.1$ and $K_{V} 1.2$. Their expression closely matches that of the CAM Caspr1, known to occur at paranodes (Salzer, 2003). Sousa et al. (2009) showed that Caspr 1 is necessary for retention of KCNQ4 in the calyx membrane and for maintaining appropriate synaptic cleft width. We report that contactin labeling is comparable to the Caspr1 pattern. Both CAMs may together stabilize other $\mathrm{K}_{\mathrm{V}}$ channels in this domain, such as KCNQ2, KCNQ5, $\mathrm{K}_{\mathrm{V}} 1.1$, and $\mathrm{K}_{\mathrm{V}} 1.2$.

Several proteins localized to domain 1 are reported to associate with $\mathrm{Na}_{\mathrm{V}}$ subunits in other tissues: contactin (KazarinovaNoyes et al., 2001; Rush et al., 2005), tenascin-C (Srinivasan et al., 1998; Evers et al., 2002; Dityatev and Schachner, 2006; Ullian and Dityatev, 2006), and dystrophin (Byers et al., 1991, 1993; Kim et 

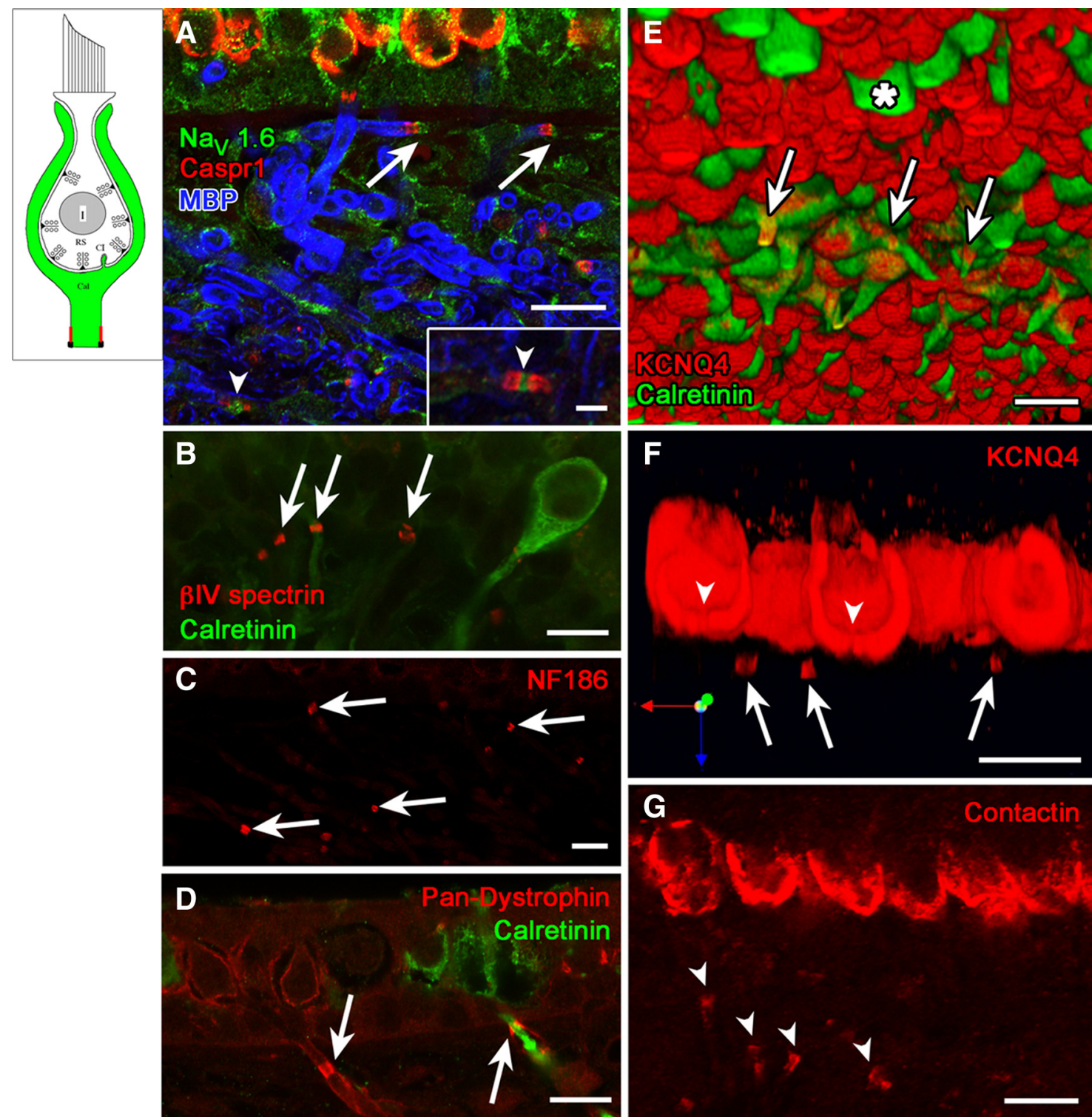

Figure 4. Domain 4, the heminodal membrane adjacent to the first internode, was marked by several ion channel and scaffolding proteins that mark nodes or initial segments in other tissues. $A$, Flattened projection of a confocal stack of images of the utricular epithelium and underlying stroma, where distal afferent fibers course before penetrating the basement membrane to approach the hair cells. Two heminodes (arrows) were labeled with the nodal markers Caspr1 (red) and $\mathrm{Na}_{v} 1.6$ (green). They are located next to the first internodes, labeled by myelin basic protein (MBP, blue). Inset shows higher magnification of a full node (arrowhead, between two paranodes) from within the stroma, labeled with the same markers. Another full node is indicated in main panel (arrowhead). Heminodes (arrows) were also immunoreactive to antibodies against such other nodal markers as $\beta I V$ spectrin (B), neurofascin186 (NF186, C), and pan-dystrophin (D). Note that the pan-dystrophin label in $\boldsymbol{D}$ encircles the cytoplasmic calretinin label of a calyx-only afferent, consistent with a membrane association. $\boldsymbol{E}$, Three-dimensional reconstruction showing the underside of a whole-mount utricular macula. Striolar calyx-only afferents and extrastriolar type II hair cells (asterisk) are calretinin-positive (green). KCNQ4 antibody (red) labeled calyces and the heminodes (arrows) of striolar calyx-only afferents. The remaining structures are the inner calyx surfaces (domain 1), marked with dense KCNQ4 label (red) and viewed from below. $F$, A longitudinal section through striolar calyces from the same whole-mount utricular macula shown in Figure 1D, showing holes (arrowheads) in the bottom of the intense KCNQ4 label and several KCNQ4-positive heminodes (arrows). $\mathbf{G}$, Contactin antibody (arrowheads) labeled paraheminodes in addition to domain 1. Comparison with $\boldsymbol{F}$ shows that heminodes are farther from the hair cell in these peripheral-zone afferents than in central-zone afferents. Scale bars: $A-G, 10 \mu \mathrm{m} ; A$, inset, $2.5 \mu \mathrm{m}$.

al., 1992; Saito et al., 2003; Occhi et al., 2005). Thus, $\mathrm{Na}_{\mathrm{V}} 1.5$ subunits in domain 1 may associate with any or all of these proteins. Contactin may regulate current density and expression of $\mathrm{Na}_{\mathrm{V}} 1.5$ channels, as it is thought to do for $\mathrm{Na}_{\mathrm{V}} 1.8$ and 1.9 subunits (Kazarinova-Noyes et al., 2001; Isom, 2002; Rush et al., 2005). Tenascin- $C$ contributes to the electron-dense cleft material in the synaptic cleft of domain 1 and could interact with $\mathrm{Na}_{\mathrm{V}} \beta$ subunits and/or contactin in domain 1 to stabilize the Na channels (Zisch et al., 1992; Srinivasan et al., 1998). Dystrophin forms a complex with dystroglycan that connects the actin cytoskeleton to the extracellular matrix, and is found where $\mathrm{Na}_{\mathrm{V}}$ channels are present in high density, for example, the deep folds of the neuromuscular junction (Byers et al., 1991), nodes (Byers et al., 1993; Occhi et al., 2005), and postsynaptic densities (Kim et al., 1992).

Thus, a complex involving contactin, tenascin-C, dystrophin, and Casprl may hold both $\mathrm{K}_{\mathrm{V}}$ and $\mathrm{Na}_{\mathrm{V}}$ channels at high density and in specific subdomains within the calyceal synaptic cleft. Analogous roles are proposed for agrin and laminin at the neuromuscular junction and for reelins and integrins at forming synapses (Dityatev and Schachner, 2003; Ullian and Dityatev, 2006).

The between-zones differences we report in ion channel expression in domain 1 may play a role in differentiating afferent 
A

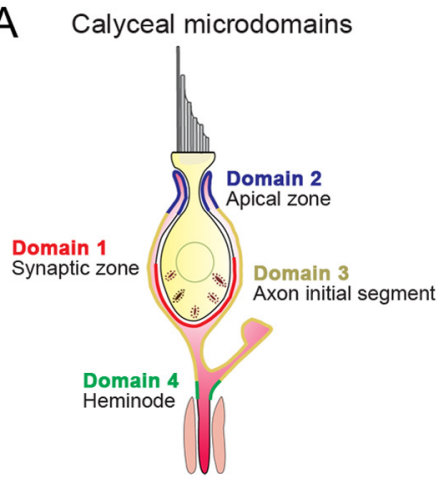

C

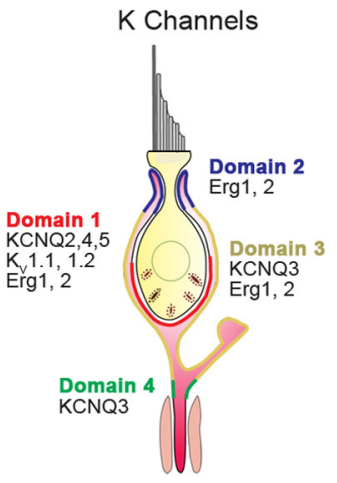

E
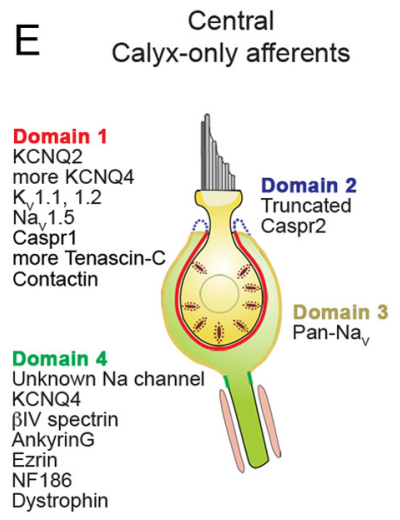

Figure 5. Ion channels and their associated proteins form calyceal microdomains in patterns that vary with afferent class and epithelial location. Most calyx endings belong to dimorphic afferents, which comprise $70-80 \%$ of vestibular afferents and innervate both central and peripheral zones of the epithelia. Domain 1 in peripheral/extrastriolar dimorphic afferents $(\boldsymbol{A}-\boldsymbol{D})$ neither extends as high nor contains as many synaptic ribbons (Lysakowski and Goldberg, 1997) as domain 1 in central/striolar afferents, whether calyx-only $(\boldsymbol{E})$ or dimorphic $(\boldsymbol{F})$. Domain 2 of peripheral dimorphic calyces is more extensive, corresponding to the longer, thinner necks of peripheral type I hair cells (Lysakowski and Goldberg, 1997). For the peripheral dimorphic calyces $(\boldsymbol{A}-\boldsymbol{D})$, we separately summarize calyceal microdomains $(\boldsymbol{A})$, scaffolding proteins $(\boldsymbol{B}), \mathrm{K}_{\mathrm{v}}$ channels $(\boldsymbol{C})$, and $\mathrm{Na}_{\mathrm{v}}$ channels (D). $\boldsymbol{E}$, Calyx-only afferents, which are restricted to central zones, appear to have a truncated domain 2 and do not express many of the proteins found in dimorphic calyces. $\boldsymbol{F}$, In central dimorphic afferents, the synaptic zone (domain 1) extends farther upward than in peripheral dimorphic afferents. Central afferents of both types $(\boldsymbol{E}, \boldsymbol{F})$ express more KCNQ4 and tenascin-C than do peripheral dimorphic afferents.

firing patterns between epithelial zones (Smith and Goldberg, 1986; Baird et al., 1988; Goldberg et al., 1990a; Kalluri et al., 2010). Recent work has specifically proposed that low-voltageactivated channels $\left(\mathrm{K}_{\mathrm{V}} 1\right.$ and $\left.\mathrm{KCNQ}\right)$ help make the firing of central afferents irregular (Iwasaki et al., 2008; Kalluri et al., 2010). KCNQ4 immunolabeling correlates with irregular spike timing: it is more extensive and intense in the central-zone calyces of irregular afferents than in the peripheral-zone calyces of regular afferents. Furthermore, M-current through KCNQ channels in calyces might be modulated by G-protein-coupled receptors activated by acetylcholine, ATP, CGRP, opioid peptides, or GABA released from efferent terminals onto calyx outer faces. In that case, the greater expression of KCNQ4 in central calyces could contribute to the greater effect of efferent activation on irregular afferents (Holt et al., 2011).

KCNQ4 is present at high density on the calyx inner face (domain 1) and much lower density on the outer face (domain 3; see Fig. $1 D$ and Lysakowski and Price, 2003). In heterologous expression systems, KCNQ4 can form homomeric channels ( $\varnothing \varnothing-$ gaard et al., 2001; Xu et al., 2007) and can heteromultimerize with KCNQ2, KCNQ3, and KCNQ5 (Howard et al., 2007; Xu et al., 2007; Bal et al., 2008). Our results suggest that KCNQ4 could partner with KCNQ2 in domain 1 of any calyx (Fig. $1 A$ ). In peripheral dimorph calyces, KCNQ4 could also partner with KCNQ5 on the inner face (domain 1; Fig. 1C) and KCNQ3 on the outer face (domain 3; Fig. 3D).

Immunoreactivity for erg subunits was much stronger in calyces of dimorphic afferents than in calyces of calyx-only afferents. This difference explains the reduced erg staining previously noted in central zones in immature epithelia (Hurley et al., 2006). Again, such zonal differences in M-like channel expression have the potential to shape afferent discharge regularity and/or efferent responses.

$\mathrm{Na}_{\mathrm{V}} 1.5$, localized to domain 1 , includes an amino acid sequence that shifts activation and inactivation voltage ranges negative relative to tetrodotoxin-sensitive $\mathrm{Na}_{\mathrm{V}}$ isoforms (Camacho et al., 2006). In this way, the voltage range of $\mathrm{Na}_{\mathrm{V}}$ channel activation in calyces may be matched with that of nearby KCNQ and erg channels (Hurley et al., 2006). Either $\mathrm{Na}_{\mathrm{V}} 1.5$ or $\mathrm{Na}_{\mathrm{V}} 1.6$ could contribute to a persistent $\mathrm{Na}_{\mathrm{V}}$ current (Holt et al., 2007; Wooltorton et al., 2007), which could shape spike timing. In the rat utricular macula, $\mathrm{Na}_{\mathrm{V}} 1.5$ immunoreactivity is strongest in the striola, at least up to P21 (Wooltorton et al., 2007); thus, $\mathrm{Na}_{\mathrm{V}} 1.5$ is also a candidate to contribute to zonal differences in discharge regularity.

Domain 2, the apical calyx membrane, is defined both by what is expressed and what is not expressed. Antibodies against $\beta \mathrm{IV}$ spectrin, Caspr2, erg1, and erg2 labeled domain 2 more than other zones. Antibodies that labeled domain 3 and not domain 2 include those against $\mathrm{Na}_{\mathrm{V}}$ channels, dystrophins, KCNQ3, and ankyrinB. Because $\beta$ IV spectrin associates with $\mathrm{Na}_{\mathrm{V}}$ channels at nodes, and Caspr2 associates with $\mathrm{K}_{\mathrm{V}}$ channels at juxtaparanodes (Arroyo and Scherer, 2000), domain 2 may express yet-to-beidentified voltage-gated channels.

Domain 2 has been proposed as a possible source of retrograde feedback from calyces to hair cells, based on immunolocalization of such presynaptic proteins as rab3A (Dechesne et al., 1997), synaptophysin (Scarfone et al., 1988; Dechesne et al., 1997), synapsin I (Scarfone et al., 1988), syntaxin, SNAP25, and synaptotagmin (Demêmes et al., 2000). Calyces might release neuropeptides (Scarfone et al., 1996) or glutamate (Devau et al., 1993) onto the type I hair cell. Detailed ultrastructural studies in rodents have revealed no postsynaptic densities in hair cell membranes adjacent to domain 2, but clusters of dense-cored vesicles are seen in domain 2 in squirrel monkey calyces (A. Lysakowski, personal observations). Dense-cored vesicles are consistent with the neuropeptide hypothesis, and because they release their contents away from active zones (Lysakowski et al., 1999; Shakiryanova et al., 2005), postsynaptic densities are unnecessary.

Domain 2 appears to be lacking in most calyx-only afferents (Figs. $1 H, 2 A-C, 5 E$ ), another zonal difference that could influ- 
Table 2. Comparison of calyx proteins to proteins in nodes of Ranvier and initial segments

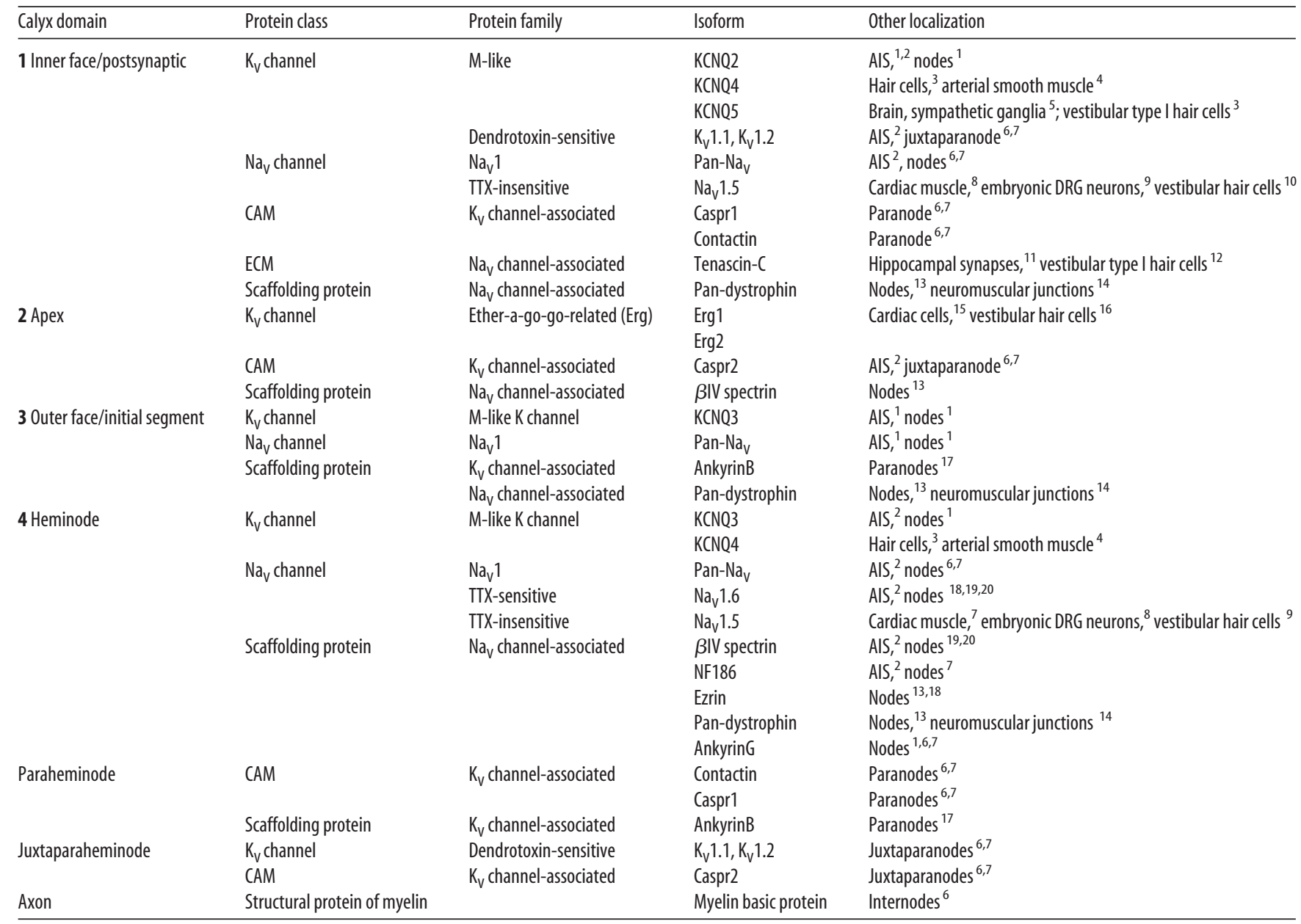

AIS, Axon initial segment; CAM, cell adhesion molecule; DRG, dorsal root ganglion; ECM, extracellular matrix protein; TTX, tetrodotoxin.

${ }^{1}$ Bennett and Healy (2009), Cooper (2011); ${ }^{2}$ Hedstrom et al. (2007), Ogawa and Rasband (2008); ${ }^{3}$ Kharkovets et al. $(2000,2006) ;{ }^{4} \mathrm{Ng}$ et al. (2011); ${ }^{5}$ Schroeder et al. (2000), Tzingounis et al. (2010); ${ }^{6}$ Arroyo and Scherer (2000); ${ }^{7}$ Peles and Salzer (2000); ${ }^{8}$ Abriel and Kass (2005); ${ }^{9}$ Rush et al. (2007); ${ }^{10}$ Wooltorton et al. (2007); ${ }^{11}$ Dityatev and Schachner (2006), Ullian and Dityatev (2006), Dityatev et al. (2010); ${ }^{12}$ Swartz and Santi (1999), Warchol and Speck (2007); ${ }^{13}$ Occhi et al. (2005); ${ }^{14}$ Pilgram et al. (2010); ${ }^{15}$ Schwarz and Bauer (2004); ${ }^{16}$ Hurley et al. (2006); ${ }^{17}$ Ogawa et al. (2006); ${ }^{18}$ Leterrier et al. (2011); ${ }^{19}$ Salzer (2003); ${ }^{20}$ Salzer et al. (2008).

ence afferent physiology. In particular, retrograde feedback from the calyx to the hair cell might be missing at calyx-only synapses, which are principally found in central and striolar zones.

In domain 3, we identified many proteins characteristic of axonal initial segments, but there are also some differences. To our knowledge, the combination of ion channels does not match any of those described in central neurons, although some diversity of expression has been reported for axonal initial segments (Lorincz and Nusser, 2008). For example, olfactory mitral cells express $K_{\mathrm{V}} 1.2$, layer 5 pyramidal cells also express $K_{\mathrm{V}} 1.1$, and Purkinje cells express neither (Lorincz and Nusser, 2008). Domain 3 of the vestibular calyx resembles the axonal initial segment in that it expresses a gradient of ion channels and scaffolding proteins. In addition to ion channels, domain 3 contains ankyrinB, which anchors $\mathrm{Na}^{+}-\mathrm{K}^{+}$ATPases and $\mathrm{Na}^{+}-\mathrm{Ca}^{2+}$ exchangers in heart (Mohler et al., 2005) and retina (Kizhatil et al., 2009). $\mathrm{Na}^{+}-\mathrm{Ca}^{2+}$ exchangers and the $\alpha 3 \beta 1$ isoform of $\mathrm{Na}^{+}-\mathrm{K}^{+}$ ATPase have been reported within the vestibular sensory epithelium (ten Cate et al., 1994; Boyer et al., 1999), but resolution was not sufficient to localize either to presynaptic or postsynaptic membranes. Unlike some axonal initial segments, domain 3 does not express $\beta \mathrm{IV}$ spectrin and neurofascin 186.

Finally, domain 4 contains many known nodal proteins (Peles and Salzer, 2000; Salzer, 2003; Dityatev and Schachner, 2006;
Ullian and Dityatev, 2006) and resembles in its organization onehalf of a full node (Fig. 4A, inset). Many vestibular heminodes were recognized by the juxtaposition of $\mathrm{Na}_{\mathrm{V}} 1.6$, the most common nodal $\mathrm{Na}_{\mathrm{V}}$ channel, with the paranodal protein Caspr1 and the internodal protein myelin basic protein. Scaffolding proteins at nodes of Ranvier ( $\beta$ IV spectrin and neurofascin 186) also label vestibular afferent heminodes intensely (Fig. $4 B, C$ ). The expression of $\mathrm{K}_{\mathrm{V}} 7$ subunits (KCNQ3, but not KCNQ2, at dimorphic heminodes and KCNQ4 at calyx-only heminodes) differs from the combination of KCNQ2 and KCNQ3 expression reported at other axonal nodes (Pan et al., 2006; Bennett and Healy, 2009).

The spike trigger zone in eighth nerve afferents has been a subject of speculation (Goldberg, 1996; Hossain et al., 2005). The presence of many known nodal proteins in domain 4 suggests that the heminode immediately below calyces may be a spike trigger zone, but does not rule out a more distant locus (Palmer and Stuart, 2006; Bean, 2007). Furthermore, the location of spike initiation may vary with zone, given that peripheral dimorphic afferents have more extensive arbors with longer unmyelinated portions (Fig. 4A, F, G).

In summary, the calyx terminal combines unique features of dendrites and initial segments in a highly ordered, novel arrangement. The large size of the ending has allowed us to define several regions, or microdomains, each characterized by a distinct set of ion chan- 
nels, neurotransmitter receptors, and accessory proteins. None of the antibodies we used produced detectable labeling of bouton terminals on type II cells. The much smaller surface areas of bouton endings $\left(5-10 \mu \mathrm{m}^{2}\right)$ compared with calyx endings $\left(\sim 1000 \mu \mathrm{m}^{2}\right)$ may be less able to accommodate microdomains.

\section{Notes}

Supplemental Material, including a movie showing a 3D reconstruction of KCNQ4 immunolabeling in the utricular macula, is available at http://www.uic.edu/depts/mcan/Vestibular_Calyx_Model.htm. Threedimensional reconstruction of a segment of vestibular sensory epithelium from the utricular macula. An antibody to KCNQ4, a low-voltage activated potassium channel subunit, intensely labels Domain 1, the inner surface of the calyx, while the outer surface (Domain 3, seen at 11-14 s) is much less intensely labeled. A small subset of heminodes in central complex calyces, likely calyx-only afferents, is also labeled. Gaps in immunoreactivity are observed in the bottom of each calyx. This material has not been peer reviewed.

\section{References}

Abriel H, Kass RS (2005) Regulation of the voltage-gated cardiac sodium channel Nav1.5 by interacting proteins. Trends Cardiovasc Med 15:35- 40 .

Arroyo EJ, Scherer SS (2000) On the molecular architecture of myelinated fibers. Histochem Cell Biol 113:1-18.

Baird RA, Desmadryl G, Fernández C, Goldberg JM (1988) The vestibular nerve of the chinchilla. II. Relation between afferent response properties and peripheral innervation patterns in the semicircular canals. J Neurophysiol 60:182-203.

Bal M, Zhang J, Zaika O, Hernandez CC, Shapiro MS (2008) Homomeric and heteromeric assembly of KCNQ $(\mathrm{Kv} 7) \mathrm{K}^{+}$channels assayed by total internal reflection fluorescence/fluorescence resonance energy transfer and patch clamp analysis. J Biol Chem 283:30668-30676.

Bao H, Wong WH, Goldberg JM, Eatock RA (2003) Voltage-gated calcium channel currents in type I and type II hair cells isolated from the rat crista. J Neurophysiol 90:155-164.

Bean BP (2007) The action potential in mammalian central neurons. Nat Rev Neurosci 8:451-465.

Bennett V, Healy J (2009) Membrane domains based on ankyrin and spectrin associated with cell-cell interactions. Cold Spring Harb Perspect Biol 1:a003012.

Black JA, Renganathan M, Waxman SG (2002) Sodium channel Na(v)1.6 is expressed along nonmyelinated axons and it contributes to conduction. Brain Res Mol Brain Res 105:19-28.

Bonsacquet J, Brugeaud A, Compan V, Desmadryl G, Chabbert C (2006) AMPA type glutamate receptor mediated neurotransmission at turtle vestibular calyx synapse. J Physiol 576:63-71.

Boyer C, Sans A, Vautrin J, Chabbert C, Lehouelleur J (1999) $\mathrm{K}^{+}$dependence of $\mathrm{Na}^{+}-\mathrm{Ca}^{2+}$ exchange in guinea-pig type I vestibular sensory cells. Eur J Neurosci 11:1955-1959.

Byers TJ, Kunkel LM, Watkins SC (1991) The subcellular distribution of dystrophin in mouse skeletal, cardiac, and smooth muscle. J Cell Biol 115:411-421.

Byers TJ, Lidov HG, Kunkel LM (1993) An alternative dystrophin transcript specific to peripheral nerve. Nat Genet 4:77-81.

Camacho JA, Hensellek S, Rougier JS, Blechschmidt S, Abriel H, Benndorf K, Zimmer T (2006) Modulation of Nav1.5 channel function by an alternatively spliced sequence in the DII/DIII linker region. J Biol Chem 281:9498-9506.

Chabbert C, Mechaly I, Sieso V, Giraud P, Brugeaud A, Lehouelleur J, Couraud F, Valmier J, Sans A (2003) Voltage-gated $\mathrm{Na}^{+}$channel activation induces both action potentials in utricular hair cells and brainderived neurotrophic factor release in the rat utricle during a restricted period of development. J Physiol 553:113-123.

Chambard JM, Chabbert C, Sans A, Desmadryl G (1999) Developmental changes in low and high voltage-activated calcium currents in acutely isolated mouse vestibular neurons. J Physiol 518:141-149.

Chen JW, Eatock RA (2000) Major potassium conductance in type I hair cells from rat semicircular canals: characterization and modulation by nitric oxide. J Neurophysiol 84:139-151.

Chung HJ, Jan YN, Jan LY (2006) Polarized axonal surface expression of neuronal KCNQ channels is mediated by multiple signals in the KCNQ2 and KCNQ3 C-terminal domains. Proc Natl Acad Sci U S A 103:8870-8875.

Cooper EC (2011) Made for "anchorin": Kv7.2/7.3 (KCNQ2/KCNQ3) channels and the modulation of neuronal excitability in vertebrate axons. Semin Cell Dev Biol 22:185-192.

Cooper EC, Aldape KD, Abosch A, Barbaro NM, Berger MS, Peacock WS, Jan YN, Jan LY (2000) Colocalization and coassembly of two human brain M-type potassium channel subunits that are mutated in epilepsy. Proc Natl Acad Sci U S A 97:4914-4919.

Cooper EC, Harrington E, Jan YN, Jan LY (2001) M channel KCNQ2 subunits are localized to key sites for control of neuronal network oscillations and synchronization in mouse brain. J Neurosci 21:9529-9540.

Dechesne CJ, Kauff C, Stettler O, Tavitian B (1997) Rab3A immunolocalization in the mammalian vestibular end-organs during development and comparison with synaptophysin expression. Brain Res Dev Brain Res 99:103-111.

Demêmes D, Seoane A, Venteo S, Desmadryl G (2000) Efferent function of vestibular afferent endings? Similar localization of N-type calcium channels, synaptic vesicle and synaptic membrane-associated proteins. Neuroscience 98:377-384.

Desai SS, Zeh C, Lysakowski A (2005a) Comparative morphology of rodent vestibular periphery. I. Saccular and utricular maculae. J Neurophysiol 93:251-266.

Desai SS, Ali H, Lysakowski A (2005b) Comparative morphology of rodent vestibular periphery. II. Cristae ampullares. J Neurophysiol 93:267-280.

Devau G, Lehouelleur J, Sans A (1993) Glutamate receptors on type I vestibular hair cells of guinea-pig. Eur J Neurosci 5:1210-1217.

Devaux JJ, Kleopa KA, Cooper EC, Scherer SS (2004) KCNQ2 is a nodal K ${ }^{+}$ channel. J Neurosci 24:1236-1244.

Dityatev A, Schachner M (2003) Extracellular matrix molecules and synaptic plasticity. Nat Rev Neurosci 4:456-468.

Dityatev A, Schachner M (2006) The extracellular matrix and synapses. Cell Tissue Res 326:647-654.

Dityatev A, Schachner M, Sonderegger P (2010) The dual role of the extracellular matrix in synaptic plasticity and homeostasis. Nat Rev Neurosci 11:735-746.

Dodd J, Morton SB, Karagogeos D, Yamamoto M, Jessell TM (1988) Spatial regulation of axonal glycoprotein expression on subsets of embryonic spinal neurons. Neuron 1:105-116.

Dou H, Vazquez AE, Namkung Y, Chu H, Cardell EL, Nie L, Parson S, Shin HS, Yamoah EN (2004) Null mutation of alpha1D $\mathrm{Ca}^{2+}$ channel gene results in deafness but no vestibular defect in mice. J Assoc Res Otolaryngol 5:215-226.

Dulon D, Safieddine S, Jones SM, Petit C (2009) Otoferlin is critical for a highly sensitive and linear calcium-dependent exocytosis at vestibular hair cell ribbon synapses. J Neurosci 29:10474-10487.

Eatock RA, Songer JE (2011) Vestibular hair cells and afferents: two channels for head motion signals. Annu Rev Neurosci 34:501-534.

Evers MR, Salmen B, Bukalo O, Rollenhagen A, Bösl MR, Morellini F, Bartsch U, Dityatev A, Schachner M (2002) Impairment of L-type $\mathrm{Ca}^{2+}$ channel-dependent forms of hippocampal synaptic plasticity in mice deficient in the extracellular matrix glycoprotein tenascin-C. J Neurosci 22:7177-7194.

Fernández C, Baird RA, Goldberg JM (1988) The vestibular nerve of the chinchilla. I. Peripheral innervation patterns in the horizontal and superior semicircular canals. J Neurophysiol 60:167-181.

Fernández C, Goldberg JM, Baird RA (1990) The vestibular nerve of the chinchilla. III. Peripheral innervation patterns in the utricular macula. J Neurophysiol 63:767-780.

Goldberg JM (1996) Theoretical analysis of intercellular communication between the vestibular type I hair cell and its calyx ending. J Neurophysiol 76:1942-1957.

Goldberg JM (2000) Afferent diversity and the organization of central vestibular pathways. Exp Brain Res 130:277-297.

Goldberg JM, Desmadryl G, Baird RA, Fernández C (1990a) The vestibular nerve of the chinchilla. IV. Discharge properties of utricular afferents. J Neurophysiol 63:781-790.

Goldberg JM, Desmadryl G, Baird RA, Fernández C (1990b) The vestibular nerve of the chinchilla. V. Relation between afferent discharge properties and peripheral innervation patterns in the utricular macula. J Neurophysiol 63:791-804.

Gulley RL, Bagger-Sjöbäck D (1979) Freeze-fracture studies on the synapse 
between the type I hair cell and the calyceal terminal in the guinea-pig vestibular system. J Neurocytol 8:591-603.

Hedstrom KL, Xu X, Ogawa Y, Frischknecht R, Seidenbecher CI, Shrager P, Rasband MN (2007) Neurofascin assembles a specialized extracellular matrix at the axon initial segment. J Cell Biol 178:875-886.

Holt JC, Chatlani S, Lysakowski A, Goldberg JM (2007) Quantal and nonquantal transmission in calyx-bearing fibers of the turtle posterior crista. J Neurophysiol 98:1083-1101.

Holt JC, Lysakowski A, Goldberg JM (2011) The efferent vestibular system. In: Auditory and vestibular efferents (Ryugo DD, Fay RR, Popper AN, eds), pp 135-186. New York: Springer.

Hossain WA, Antic SD, Yang Y, Rasband MN, Morest DK (2005) Where is the spike generator of the cochlear nerve? Voltage-gated sodium channels in the mouse cochlea. J Neurosci 25:6857-6868.

Howard RJ, Clark KA, Holton JM, Minor DL Jr (2007) Structural insight into KCNQ (Kv7) channel assembly and channelopathy. Neuron 53:663-675.

Hurley KM, Gaboyard S, Zhong M, Price SD, Wooltorton JR, Lysakowski A, Eatock RA (2006) M-like $\mathrm{K}^{+}$currents in type I hair cells and calyx afferent endings of the developing rat utricle. J Neurosci 26:10253-10269.

Huss D, Navaluri R, Faulkner KF, Dickman JD (2010) Development of otolith receptors in Japanese quail. Dev Neurobiol 70:436-455.

Isom LL (2002) The role of sodium channels in cell adhesion. Front Biosci 7:12-23.

Iwasaki S, Chihara Y, Komuta Y, Ito K, Sahara Y (2008) Low-voltageactivated potassium channels underlie the regulation of intrinsic firing properties of rat vestibular ganglion cells. J Neurophysiol 100:2192-2204.

Kalluri R, Xue J, Eatock RA (2010) Ion channels set spike timing regularity of mammalian vestibular afferent neurons. J Neurophysiol 104:2034-2051.

Kazarinova-Noyes K, Malhotra JD, McEwen DP, Mattei LN, Berglund EO, Ranscht B, Levinson SR, Schachner M, Shrager P, Isom LL, Xiao ZC (2001) Contactin associates with $\mathrm{Na}^{+}$channels and increases their functional expression. J Neurosci 21:7517-7525.

Kharkovets T, Hardelin JP, Safieddine S, Schweizer M, El-Amraoui A, Petit C, Jentsch TJ (2000) KCNQ4, a $\mathrm{K}^{+}$channel mutated in a form of dominant deafness, is expressed in the inner ear and the central auditory pathway. Proc Natl Acad Sci U S A 97:4333-4338.

Kharkovets T, Dedek K, Maier H, Schweizer M, Khimich D, Nouvian R, Vardanyan V, Leuwer R, Moser T, Jentsch TJ (2006) Mice with altered $\mathrm{KCNQ} 4 \mathrm{~K}^{+}$channels implicate sensory outer hair cells in human progressive deafness. EMBO J 25:642-652.

Kim TW, Wu K, Xu JL, Black IB (1992) Detection of dystrophin in the postsynaptic density of rat brain and deficiency in a mouse model of Duchenne muscular dystrophy. Proc Natl Acad Sci U S A 89:11642-11644.

Kizhatil K, Sandhu NK, Peachey NS, Bennett V (2009) Ankyrin-B is required for coordinated expression of beta-2-spectrin, the Na/K-ATPase and the $\mathrm{Na} / \mathrm{Ca}$ exchanger in the inner segment of rod photoreceptors. Exp Eye Res 88:57-64.

Kordeli E, Lambert S, Bennett V (1995) AnkyrinG. A new ankyrin gene with neural-specific isoforms localized at the axonal initial segment and node of Ranvier. J Biol Chem 270:2352-2359.

Lacas-Gervais S, Guo J, Strenzke N, Scarfone E, Kolpe M, Jahkel M, De Camilli P, Moser T, Rasband MN, Solimena M (2004) BetaIVSigma1 spectrin stabilizes the nodes of Ranvier and axon initial segments. J Cell Biol 166:983-990.

Lai HC, Jan LY (2006) The distribution and targeting of neuronal voltagegated ion channels. Nat Rev Neurosci 7:548-562.

Leterrier C, Brachet A, Dargent B, Vacher H (2011) Determinants of voltage-gated sodium channel clustering in neurons. Semin Cell Dev Biol 22:171-177.

Lorincz A, Nusser Z (2008) Cell-type-dependent molecular composition of the axon initial segment. J Neurosci 28:14329-14340.

Lysakowski A, Goldberg JM (1997) A regional ultrastructural analysis of the cellular and synaptic architecture in the chinchilla cristae ampullares. J Comp Neurol 389:419-443.

Lysakowski A, Goldberg JM (2004) Morphophysiology of the vestibular sensory periphery. In: The vestibular system. (Highstein SM, Fay RR, Popper AN, eds), pp 57-152. New York: Springer.

Lysakowski A, Goldberg JM (2008) Ultrastructural analysis of the cristae ampullares in the squirrel monkey (Saimiri sciureus). J Comp Neurol 511:47-64.
Lysakowski A, Price SD (2003) Potassium channel localization in sensory epithelia of the rat inner ear. Assoc Res Otolaryngol Abstr 26:1534.

Lysakowski A, Singer M (2000) Nitric oxide synthase localized in a subpopulation of vestibular efferents with NADPH diaphorase histochemistry and nitric oxide synthase immunohistochemistry. J Comp Neurol 427:508-521.

Lysakowski A, Figueras H, Price SD, Peng YY (1999) Dense-cored vesicles, smooth endoplasmic reticulum, and mitochondria are closely associated with non-specialized parts of plasma membrane of nerve terminals: implications for exocytosis and calcium buffering by intraterminal organelles. J Comp Neurol 403:378-390.

Matsubara A, Takumi Y, Nakagawa T, Usami S, Shinkawa H, Ottersen OP (1999) Immunoelectron microscopy of AMPA receptor subunits reveals three types of putative glutamatergic synapse in the rat vestibular end organs. Brain Res 819:58-64.

Mohler PJ, Davis JQ, Bennett V (2005) Ankyrin-B coordinates the Na/K ATPase, $\mathrm{Na} / \mathrm{Ca}$ exchanger, and InsP3 receptor in a cardiac T-tubule/SR microdomain. PLoS Biol 3:e423.

Ng FL, Davis AJ, Jepps TA, Harhun MI, Yeung SY, Wan A, Reddy M, Melville D, Nardi A, Khong TK, Greenwood IA (2011) Expression and function of the $\mathrm{K}^{+}$channel KCNQ genes in human arteries. Br J Pharmacol 162:42-53.

Occhi S, Zambroni D, Del Carro U, Amadio S, Sirkowski EE, Scherer SS, Campbell KP, Moore SA, Chen ZL, Strickland S, Di Muzio A, Uncini A, Wrabetz L, Feltri ML (2005) Both laminin and Schwann cell dystroglycan are necessary for proper clustering of sodium channels at nodes of Ranvier. J Neurosci 25:9418-9427.

Ogawa Y, Rasband MN (2008) The functional organization and assembly of the axon initial segment. Curr Opin Neurobiol 18:307-313.

Ogawa Y, Schafer DP, Horresh I, Bar V, Hales K, Yang Y, Susuki K, Peles E, Stankewich MC, Rasband MN (2006) Spectrins and ankyrinB constitute a specialized paranodal cytoskeleton. J Neurosci 26:5230-5239.

Palmer LM, Stuart GJ (2006) Site of action potential initiation in layer 5 pyramidal neurons. J Neurosci 26:1854-1863.

Pan Z, Kao T, Horvath Z, Lemos J, Sul JY, Cranstoun SD, Bennett V, Scherer SS, Cooper EC (2006) A common ankyrin-G-based mechanism retains KCNQ and $\mathrm{Na}_{\mathrm{V}}$ channels at electrically active domains of the axon. J Neurosci 26:2599-2613.

Peles E, Salzer JL (2000) Molecular domains of myelinated axons. Curr Opin Neurobiol 10:558-565.

Pilgram GS, Potikanond S, Baines RA, Fradkin LG, Noordermeer JN (2010) The roles of the dystrophin-associated glycoprotein complex at the synapse. Mol Neurobiol 41:1-21.

Rasband MN, Trimmer JS (2001) Subunit composition and novel localization of $\mathrm{K}^{+}$channels in spinal cord. J Comp Neurol 429:166-176.

Rasband MN, Peles E, Trimmer JS, Levinson SR, Lux SE, Shrager P (1999) Dependence of nodal sodium channel clustering on paranodal axoglial contact in the developing CNS. J Neurosci 19:7516-7528.

Rasband MN, Kagawa T, Park EW, Ikenaka K, Trimmer JS (2003) Dysregulation of axonal sodium channel isoforms after adult-onset chronic demyelination. J Neurosci Res 73:465-470.

Rennie KJ, Streeter MA (2006) Voltage-dependent currents in isolated vestibular afferent calyx terminals. J Neurophysiol 95:26-32.

Rivier F, Robert A, Hugon G, Bonet-Kerrache A, Nigro V, Fehrentz JA, Martinez J, Mornet D (1999) Dystrophin and utrophin complexed with different associated proteins in cardiac Purkinje fibres. Histochemical J 31:425-432.

Rush AM, Craner MJ, Kageyama T, Dib-Hajj SD, Waxman SG, Ranscht B (2005) Contactin regulates the current density and axonal expression of tetrodotoxin-resistant but not tetrodotoxin-sensitive sodium channels in DRG neurons. Eur J Neurosci 22:39-49.

Rush AM, Cummins TR, Waxman SG (2007) Multiple sodium channels and their roles in electrogenesis within dorsal root ganglion neurons. J Physiol 579:1-14.

Saito F, Moore SA, Barresi R, Henry MD, Messing A, Ross-Barta SE, Cohn RD, Williamson RA, Sluka KA, Sherman DL, Brophy PJ, Schmelzer JD, Low PA, Wrabetz L, Feltri ML, Campbell KP (2003) Unique role of dystroglycan in peripheral nerve myelination, nodal structure, and sodium channel stabilization. Neuron 38:747-758.

Salzer JL (2003) Polarized domains of myelinated axons. Neuron 40:297-318. 
Salzer JL, Brophy PJ, Peles E (2008) Molecular domains of myelinated axons in the peripheral nervous system. Glia 56:1532-1540.

Scarfone E, Demêmes D, Jahn R, De Camilli P, Sans A (1988) Secretory function of the vestibular nerve calyx suggested by presence of vesicles, synapsin I, and synaptophysin. J Neurosci 8:4640-4645.

Scarfone E, Ulfendahl M, Lundeberg T (1996) The cellular localization of the neuropeptides substance $\mathrm{P}$, neurokinin $\mathrm{A}$, calcitonin gene-related peptide and neuropeptide $\mathrm{Y}$ in guinea-pig vestibular sensory organs: a high-resolution confocal microscopy study. Neuroscience 75:587-600.

Schafer DP, Rasband MN (2006) Glial regulation of the axonal membrane at nodes of Ranvier. Curr Opin Neurobiol 16:508-514.

Schafer DP, Custer AW, Shrager P, Rasband MN (2006) Early events in node of Ranvier formation during myelination and remyelination in the PNS. Neuron Glia Biol 2:69-79.

Schroeder BC, Hechenberger M, Weinreich F, Kubisch C, Jentsch TJ (2000) KCNQ5, a novel potassium channel broadly expressed in brain, mediates M-type currents. J Biol Chem 275:24089-24095.

Schwarz JR, Bauer CK (2004) Functions of erg $\mathrm{K}^{+}$channels in excitable cells. J Cell Mol Med 8:22-30.

Schwarz JR, Glassmeier G, Cooper EC, Kao TC, Nodera H, Tabuena D, Kaji R, Bostock H (2006) KCNQ channels mediate IKs, a slow $\mathrm{K}^{+}$current regulating excitability in the rat node of Ranvier. J Physiol 573:17-34.

Scotland P, Zhou D, Benveniste H, Bennett V (1998) Nervous system defects of AnkyrinB (-/-) mice suggest functional overlap between the cell adhesion molecule L1 and 440-kD AnkyrinB in premyelinated axons. J Cell Biol 143:1305-1315.

Shakiryanova D, Tully A, Hewes RS, Deitcher DL, Levitan ES (2005) Activity-dependent liberation of synaptic neuropeptide vesicles. Nat Neurosci 8:173-178.

Smith CE, Goldberg JM (1986) A stochastic afterhyperpolarization model of repetitive activity in vestibular afferents. Biol Cybern 54:41-51.

Søgaard R, Ljungstrøm T, Pedersen KA, Olesen SP, Jensen BS (2001) KCNQ4 channels expressed in mammalian cells: functional characteristics and pharmacology. Am J Physiol Cell Physiol 280:C859-866.

Sousa AD, Andrade LR, Salles FT, Pillai AM, Buttermore ED, Bhat MA, Kachar B (2009) The septate junction protein caspr is required for structural support and retention of KCNQ4 at calyceal synapses of vestibular hair cells. J Neurosci 29:3103-3108.

Spiegel I, Salomon D, Erne B, Schaeren-Wiemers N, Peles E (2002) Caspr3 and caspr4, two novel members of the caspr family are expressed in the nervous system and interact with PDZ domains. Mol Cell Neurosci 20:283-297.

Spoendlin H (1966) Some morphofunctional and pathological aspects of the vestibular sensory epithelium. In: Second symposium on the role of the vestibular organs in space exploration, NASA SP-115, pp 99-116. Washington, DC: U.S. Government Printing Office.

Srinivasan J, Schachner M, Catterall WA (1998) Interaction of voltagegated sodium channels with the extracellular matrix molecules tenascin-C and tenascin-R. Proc Natl Acad Sci U S A 95:15753-15757.

Swartz DJ, Santi PA (1999) Immunolocalization of tenascin in the chinchilla inner ear. Hear Res 130:108-114.

ten Cate WJ, Curtis LM, Rarey KE (1994) Na,K-ATPase alpha and beta subunit isoform distribution in the rat cochlear and vestibular tissues. Hear Res 75:151-160.

Tzingounis AV, Heidenreich M, Kharkovets T, Spitzmaul G, Jensen HS, Nicoll RA, Jentsch TJ (2010) The KCNQ5 potassium channel mediates a component of the afterhyperpolarization current in mouse hippocampus. Proc Natl Acad Sci U S A 107:10232-10237.

Ullian EM, Dityatev A (2006) Extracellular matrix molecules and formation of CNS synapses. In: Molecular mechanisms of synaptogenesis (Dityatev A, El-Husseini A, eds), pp 163-179. New York: Springer.

Warchol ME, Speck JD (2007) Expression of GATA3 and tenascin in the avian vestibular maculae: normative patterns and changes during sensory regeneration. J Comp Neurol 500:646-657.

Wersäll J (1956) Studies on the structure and innervation of the sensory epithelium of the cristae ampullaris in the guinea pig. A light and electron microscopic investigation. Acta Otolaryngol Suppl 126:1-85.

Wooltorton JR, Gaboyard S, Hurley KM, Price SD, Garcia JL, Lysakowski A, Eatock RA (2007) Developmental changes in two voltage-dependent sodium currents in utricular hair cells. J Neurophysiol 97:1684-1704.

Xu T, Nie L, Zhang Y, Mo J, Feng W, Wei D, Petrov E, Calisto LE, Kachar B, Beisel KW, Vazquez AE, Yamoah EN (2007) Roles of alternative splicing in the functional properties of inner ear-specific KCNQ4 channels. J Biol Chem 282:23899-23909.

Yamashita M, Ohmori H (1990) Synaptic responses to mechanical stimulation in calyceal and bouton type vestibular afferents studied in an isolated preparation of semicircular canal ampullae of chicken. Exp Brain Res 80:475-488.

Yus-Nájera E, Muñoz A, Salvador N, Jensen BS, Rasmussen HB, Defelipe J, Villarroel A (2003) Localization of KCNQ5 in the normal and epileptic human temporal neocortex and hippocampal formation. Neuroscience 120:353-364.

Zisch AH, D'Alessandri L, Ranscht B, Falchetto R, Winterhalter KH, Vaughan L (1992) Neuronal cell adhesion molecule contactin/F11 binds to tenascin via its immunoglobulin-like domains. J Cell Biol 119:203-213. 